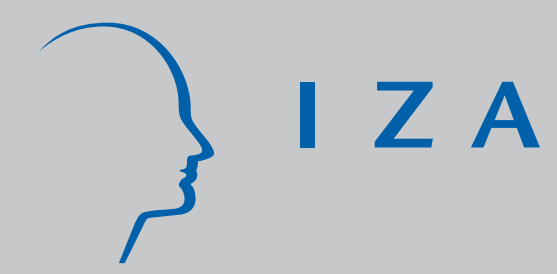

IZA DP No. 87

Educational Mismatch and Wages in Germany

Thomas K. Bauer

December 1999 


\title{
Educational Mismatch and Wages in Germany
}

\author{
Thomas K. Bauer \\ IZA, Bonn, University of Bonn and CEPR, London
}

Discussion Paper No. 87
December 1999

IZA

P.O. Box 7240

D-53072 Bonn

Germany

Tel.: +49-228-3894-0

Fax: +49-228-3894-210

Email: iza@iza.org

This Discussion Paper is issued within the framework of IZA's research area General Labor Economics. Any opinions expressed here are those of the author(s) and not those of the institute. Research disseminated by IZA may include views on policy, but the institute itself takes no institutional policy positions.

The Institute for the Study of Labor (IZA) in Bonn is a local and virtual international research center and a place of communication between science, politics and business. IZA is an independent, nonprofit limited liability company (Gesellschaft mit beschränkter Haftung) supported by the Deutsche Post AG. The center is associated with the University of Bonn and offers a stimulating research environment through its research networks, research support, and visitors and doctoral programs. IZA engages in (i) original and internationally competitive research in all fields of labor economics, (ii) development of policy concepts, and (iii) dissemination of research results and concepts to the interested public. The current research program deals with (1) mobility and flexibility of labor markets, (2) internationalization of labor markets and European integration, (3) the welfare state and labor markets, (4) labor markets in transition, (5) the future of work, (6) project evaluation and (7) general labor economics.

IZA Discussion Papers often represent preliminary work and are circulated to encourage discussion. Citation of such a paper should account for its provisional character. 
IZA Discussion Paper No. 87

December 1999

\section{ABSTRACT \\ Educational Mismatch and Wages in Germany*}

This paper contributes to the literature considering the wage effects of educational mismatch in Germany. It uses a large German panel data set for the period from 1984 to 1997 and stresses the importance of controlling for unobserved heterogeneity when analyzing the labor market effects of over- and undereducation. Using pooled OLS, the estimation results confirm those found in the existing literature. The estimated differences between adequately and inadequately educated workers become smaller or disappear totally, when controlling for unobserved heterogeneity. In contrast to the common results using only cross-sectional data, the human capital model could not be rejected once controlling for unobserved heterogeneity.

JEL Classification: I21, J31

Keywords: Overeducation, undereducation, human capital model, job competition model

Thomas K. Bauer

IZA

P.O. Box 7240

53072 Bonn

Germany

Tel.: +49-228-3894-305

FAX: +49-228-3894-210

Email: Bauer@iza.org

I want to thank Kurt Brännäs, Don DeVoretz, John Haisken-DeNew, Magnus Lofström, Anja Thalmaier, Rainer Winkelmann and Melanie Ward for their helpful comments on earlier drafts of this paper. 


\section{INTRODUCTION}

Similar to most other developed countries, Germany has experienced an increased supply of highly educated workers in the last decade. In the period from 1985 to 1995 the enrollment of students in universities increased by more than $24 \%$. In the same period, the share of the labor force with a university degree increased by 3.4 percentage points from $9.7 \%$ to $13.1 \%$. The share of unemployed with an university degree increased by 2.6 percentage points from $3.8 \%$ in 1985 to $6.4 \%$ in 1995 . At the first glance, these numbers indicate that the increased supply of high skilled workers has been accompanied by an increased demand. It might be, however, that the increased human capital of German workers is not utilized to the full due to an increased misallocation. If the growth of the supply of highly skilled workers outpaces the growth in the demand for these workers, overeducation of the work force might increase, with highly educated workers substituting the lower skilled.

The incidence and the labor market effects of educational mismatch have received increasing attention in recent years. In this literature workers are differentiated into workers which are adequately educated for the job they perform, overeducated if they have an educational attainment which is higher than that required for the job and undereducated if they have less schooling than required. Among the issues discussed in this literature are the effects of inadequate education on job and career mobility (Sicherman, 1991; Hersch, 1991; Robst, 1995a; Alba-Ramirez, 1992; Tsang, Rumberger and Levin, 1991; Sloane, Battu and Seaman, 1999) and on job satistifaction (Hersch, 1991; Tsang, Rumberger and Levin, 1991). Most of the existing studies study the wage effects of inadequate schooling (Hartog and Oosterbeck, 1988; Groot, 1993, 1996; Kiker, Santos and Oliveira, 1997; Alba-Ramirez, 1992; Hersch, 1991; Cohn and Kahn, 1995; Duncan and Hoffman, 1981; Verdugo and Verdugo, 1989; Rumberger, 1987; Sloane, Battu and Seaman, 1999). In general, the latter studies find that the returns to years of overschooling are positive, but significantly lower than the returns to adequate education and that the returns to undereducation are negative. ${ }^{1}$

See Groot (1993) and Kiker, Santos and Oliveira (1997) for a survey of the wage effects of inadequate education. 
This paper expands the existing literature in two respects. First, using a panel data set - the German Socioeconomic Panel (GSOEP) - the paper provides the first investigation of the extent and the wage effects of over- and underschooling in Germany using two different measures of inadequate education. Second, existing studies of the labor market effects of educational mismatch are based solely on cross-section data. It may be the case that the results of these studies are biased due to unobserved heterogeneity. Controlling for unobserved heterogeneity might for example be important when individuals with lower innate ability need more education to attain a job for which they are formally overeducated. Therefore, this paper utilize the panel structure of the data set by estimation random and fixed effects panel estimators to analyze whether previous results concerning the wage effects of inadequate schooling remain when controlling for unobserved individual effects.

Section II gives a brief description of the data set together with a discussion of possible measures of over- and undereducation. This section further outlines the incidence and development of educational mismatch in Germany. The econometric approach used in the analysis is described in Section III. The estimation results are presented in Section IV. The estimation results for pooled OLS are presented first to in order to compare the wage effects of educational mismatch to the results of studies for other countries. Then the results from random and fixed effects models are presented and compared to the results from the pooled OLS estimations to analyze the importance of controlling for unobserved heterogeneity. Section V concludes.

\section{OVER- AND UNDEREDUCATION IN GERMANY}

The sample used in this study is drawn from the German Socio-Economic Panel (GSOEP), a panel data set for the years 1984 to 1997 consisting of about 13,500 individuals and 7,000 households living in Germany. All full-time employed, prime-aged males and females of German nationality were selected. Foreigners and East Germans were excluded in order to study just those individuals who received their education in a similar schooling system. In addition, self-employed and those currently in education or training were not considered. After eliminating all observations with missing values, a 
final sample of 18,647 person-year observations consisting of 2,945 individuals remained for the analysis.

Educational mismatch is usually measured as the difference between the educational attainment of an individual and the skill requirements of the job the individual performs, i.e., a worker is considered to be overeducated (undereducated) if he has more (less) education than is required for his or her job and adequately educated if his or her education just meets the job requirements. In order to classify a worker to be inadequately educated one has to estimate the amount of schooling required for a particular job. Different approaches have been discussed in the literature to determine the amount of required education. Kiker, Santos and Oliveira (1997) and Sicherman (1991) give a detailed discussion of the advantages and disadvantages of different measures of over- and undereducation.

Several studies have used an exogenous definition of schooling requirements for the particular occupation the individual is working in order to determine required schooling (Rumberger 1987; Hartog and Oosterbeck, 1988; McGoldrick and Robst, 1996; Kiker, Santos and Oliveira, 1997; Sloane, Battu and Seaman, 1999). A major criticism of this measure arises through the potential measurement errors resulting from translating categorical values of educational requirements into a single continuous variable of years of schooling (Sicherman, 1991). Furthermore, if such a measure is very rigid, misclassifications of workers as over- or undereducated might increase over time, if adjustments of schooling requirements occur due to technological progress or changes in workplace organization (Kiker, Santos and Oliveira, 1997). In Germany, there is no equivalent of an exogenous definition of schooling requirements for different occupations available, such as the Dictionary of Occupational Titles in the US. Hence, this type of measurement of educational mismatch cannot be used.

A second approach is to ask workers directly whether they are over- or undereducated for the job they perform (Sicherman, 1991; Hersch, 1991; Robst, 1995a, 1995b; McGoldrick and Robst, 1996). The main advantage of this measure is that it is jobspecific. It has been criticized, however, due to its subjective nature. Furthermore, the type of question which is used to determine educational mismatch usually refers to the education needed to get a job, not to the education necessary to perform a job. Even 
though the GSOEP provides a question about the skills required to perform the job an individual is employed in, this information is not suitable for the empirical analysis of the wage effects of inadequate education in Germany either. The categorical values provided within this question cannot be converted into a single measure of years of schooling which is comparable with the coding of actual years of schooling provided in the data set.

The following empirical analysis makes use of two other possible measures of required schooling. The first measure, which follows from Verdugo and Verdugo (1989), defines required schooling as an one-standard-deviation range around the mean level of schooling within occupations disaggregated at a 3-digit level. Workers are considered to be adequately educated if their actual education falls within this range, overeducated if their actual education is greater than one standard deviation above the mean for the specific occupation, and undereducated if their actual education is more than one standard deviation below the mean education. The main criticism of this measure has also been its subjectivity, since there is no rationale behind the arbitrary choice of one standard deviation. Furthermore, this type of measure results in estimated levels of inadequate schooling, which are far below those of other measures. As Kiker, Santos and Oliveira (1997) note, this measure is more sensitive to technological changes and changes in workplace organization than the others, potentially suggesting misleading conclusions about the development of inadequate schooling over time.

The second measure of required schooling used in this study is suggested by Kiker, Santos and Oliveira (1997). They suggest using the modal value within a given occupation to measure required schooling. Hence, workers are considered to be adequately educated if their actual education equals the mode value of education within their occupation. Those workers whose actual educational attainment is above the modal education of their specific occupation are considered to be overeducated, those whose actual education falls below the mode are considered to be undereducated. Similar to the measure of Verdugo and Verdugo (1989) the mode-index is determined within 3-digit occupations. The main advantages of this measure over the one proposed by Verdugo and Verdugo (1989) is that it is less sensitive to technological changes and that it provides estimates of inadequate schooling, which are more in line with the first two approaches. 
Table 1 shows the development of educational mismatch in Germany for the total sample and the male and female sub-samples for the years 1985, 1990 and 1995. Overall, actual years and required years of schooling have slightly increased over time. The development of educational mismatch in Germany also shows an increasing tendency between 1985 and 1995. The increase in educational mismatch is particularly strong for females, where the share of overeducated females increases from $9 \%$ in 1985 to $16 \%$ in 1995 and the average years of overeducation from 0.09 years in 1985 to 0.26 years in 1995 when using the mean-index. This development might be explained with the increasing number of female students and the increase in female labor force participation. $^{2}$

According to the mean-index, the majority of German employees are adequately educated; about $13 \%$ of the total sample is estimated to be overeducated and $10 \%$ to be undereducated. Note, that these numbers are comparable to those found in the UK (Groot, 1996), lower than those found in The Netherlands (Groot, 1993), and slightly higher than those found for Portugal (Kiker, Santos and Oliveira, 1997) and the US (Verdugo and Verdugo, 1989) when using the same definition of required education. The average years of overeducation varies between 0.12 in 1985 and 0.17 in 1995 and the average years of undereducation remain constant at around 0.07 years. The mode-index gives a slightly different picture of the incidence of educational mismatch in Germany than the meanindex. Both the average years of over- and undereducation as well as the share of employees being over- or undereducated are relatively higher and more volatile for the mode-index. The difference between the two measures reflects the different computation of the two indices. Required education for the mean-index is defined as a range around the mean years of schooling in an occupation and in the mode-index as the most frequent level of schooling. It could be expected that in the mean-index individuals have a higher probability of being classified as adequately educated than in the mode-index (Kiker, Santos and Oliveira, 1997). According to the mode-index, around one quarter of the workers are estimated to be either over- or undereducated, respectively. The average years of overeducation is slightly increasing from 0.46 years in 1985 to 0.55 years in

In West Germany, the share of enrolled female students to all students increased from $37.9 \%$ in 1985 to $40.9 \%$ in 1995 . The share of females on the labor force increased from $35.6 \%$ in 1985 to 
1990 and 1995, with the increase being lower for males than for females. Compared to the average years of overeducation, the increase in the average years of undereducation is stronger, rising from 0.47 years in 1985 to 0.64 years in 1995. The increase in the average years of undereducation is mainly driven by the males, who show an increase in both the share of undereducated males and the average years of undereducation.

\section{EMPIRICAL APPROACH}

Two basic specifications have been used in the literature to study the wage effects of inadequate schooling. Following Verdugo and Verdugo (1989), the first model can be written as:

$$
\ln Y_{i t}=\alpha_{0}+\alpha_{1} E_{i t}+\alpha_{2} O V_{i t}+\alpha_{3} U N_{i t}+X_{i t} \gamma+\varepsilon_{i t}
$$

where $\ln Y_{i t}$ denotes the $\log$ of gross real hourly wages of individual $i$ in year $t, E_{i t}$ is the actual years of schooling, $O V_{i t}$ and $U N_{i t}$ are dummy variables for overeducation and undereducation, respectively, $X_{i t}$ is a vector containing other explanatory variables with the corresponding vector of coefficients $\gamma$, and $\varepsilon_{i t}$ is an error term.

According to equation (1), educational mismatched workers are compared to similar workers with the same level of schooling who work in jobs that require the level of schooling they actually have. In the case where productivity and wages are determined by the actual level of education, the coefficients $\alpha_{2}$ and $\alpha_{3}$ are expected to be zero. If wages are determined by the education level required to perform a job, any number of years of schooling exceeding the required amount of schooling would be unproductive and the reward to these additional years would be zero. In this case an overeducated worker would earn less than a similar worker with the same level of schooling who is adequately allocated to a job and $\alpha_{2}$ would be negative. Similarly, an undereducated worker would 
earn more than an adequately allocated worker with the same education and $\alpha_{3}$ would be positive.

The second model, which is due to Duncan and Hoffman (1981), ${ }^{3}$ decomposes actual years of schooling $\left(E_{i t}\right)$ into required years of schooling $\left(E^{r}{ }_{i t}\right)$, years of overschooling $\left(E^{o}{ }_{i t}\right)$, and years of underschooling $\left(E^{u}{ }_{i t}\right)$ using the following definition:

$$
E_{i t}=E_{i t}^{r}+E_{i t}^{o}-E_{i t}^{u}
$$

where

$$
E_{i t}^{o}=\left\{\begin{array}{l}
E_{i t}-E_{i t}^{r}, \text { if } E_{i t}>E_{i t}^{r} \\
0, \text { otherwise }
\end{array} \text {, and } E_{i t}^{u}=\left\{\begin{array}{l}
E_{i t}^{r}-E_{i t}, \text { if } E_{i t}<E_{i t}^{r} \\
0, \text { otherwise }
\end{array} .\right.\right.
$$

Using this definition the second specification can be written as:

$$
\ln Y_{i t}=\beta_{0}+\beta_{1} E_{i t}^{r}+\beta_{2} E_{i t}^{o}+\beta_{3} E_{i t}^{u}+X_{i t} \gamma+\varepsilon_{i t},
$$

In this specification $\beta_{1}$ is the return to years of required schooling; $\beta_{2}$ is the return to an additional year of schooling beyond the schooling requirement compared to workers in the same occupation who have the required education, and $\beta_{3}$ is the return to a year of schooling below the schooling requirement, relative to workers in the same occupation who have the required education.

As Hartog and Oosterbeck (1988) note, two competing theoretical models, the human capital theory and the job competition theory as derived by Thurow (1975), are nested in specification (4). According to the human capital theory, earnings are not affected by the requirements of a particular job, since job level and related variables are subsumed in the age-earnings profile of a Mincer-type wage regression (Mincer, 1974). The human capital

See Groot (1993) for a survey of the empirical evidence using the Duncan-Hoffman specification. 
model emerges from equation (4) if $\beta_{1}=\beta_{2}=-\beta_{3}$. In this case, equation (4) reduces to the standard human capital earnings equation:

$$
\ln Y_{i t}=\gamma_{0}+\gamma_{1} E_{i t}+\varepsilon_{i t},
$$

In contrast to the human capital theory, the job competition theory is a demand-side theory, where marginal productivity is taken as a fixed characteristic of a particular job and is not related to the characteristics of the worker. Therefore, earnings are related to the job rather than to the worker. The job competition model emerges from equation (4) when $\beta_{2}=\beta_{3}=0$.

Equations (1), (4) and (5) are estimated for the total sample as well as the male and female sub-samples using the mean- and mode-index which were described in the previous section. The vector of other control variables, $X_{i t}$, includes age and age squared, tenure and tenure squared, a dummy for marital status, three dummies for firm size, two dummies for region, five dummies for industries and year dummies. ${ }^{4}$

So far, existing empirical studies on the wage effects of inadequate schooling are based on cross-section data. However, it might be that the results of these studies are biased due to unobserved heterogeneity of individuals. Controlling for unobserved heterogeneity might be important if individuals with lower innate ability need more education to attain a job for which they are formally overeducated. Robst (1995b) for example shows for the US, that there is a negative relationship between college quality and the probability of being overeducated and a positive relationship between college quality and the probability of leaving the overeducation status. Following this argument, one would expect that the estimated coefficients on the overeducation dummy in equation (1) will become more positive when controlling for unobserved heterogeneity, since unobserved ability and the probability to be overeducated are negatively correlated. Applying the same argument, the coefficient on the undereducation dummy should become less positive, since unobserved ability and the probability to be undereducated are positively correlated. In order to be able to draw comparisons with previous studies,

The estimation results for these additional explanatory will not be discussed. A full set of the estimation results is available on request. 
equations (1) and (4) are estimated using pooled OLS. The role of unobserved heterogeneity will be analyzed by applying random and fixed effects panel estimators. ${ }^{5}$

Table 2 contains some descriptive statistics for the total sample together with the respective overall and the between and within group variation. Table 2 shows that the required schooling and the different variables describing educational mismatch have a much lower within-group variation for the mean-index when compared to the modeindex. The low within-group variation for the variables calculated on the basis of the mean-index cast some doubts on whether the wage effects of educational mismatch could be identified in the fixed effects model.

\section{The RETURNS TO OVER- AND UNDEREDUCATION}

The estimation results on equation (1) are reported in Table 3. For the mean-index, the results for the pooled OLS suggest that overeducated workers earn $4.8 \%$ less and undereducated workers $5 \%$ more than workers with the same amount of education who are working in occupations, which fully utilize their educational level. Overeducated males do not earn significantly less than male workers with the same educational level who work in occupations they are adequately educated for. Undereducated male workers earn $7.2 \%$ more than similar workers in occupations where education requirements correspond to utilized levels. Overeducated females earn $15.4 \%$ less than similar females in occupations for which they are adequately educated for. Being undereducated, however, does not lead to a significant earnings advantage for females.

Using the mode-index, the coefficient on the overeducation dummy becomes statistically insignificant for the total sample and for males. The earnings disadvantage for overeducated females drops to $5.3 \%$. The coefficients on the undereducation dummy more than double for the full sample, increases to 0.118 for the male sample and becomes significant for the female sample. Overall, the estimation results using pooled OLS are in line with previous studies using the same specification, i.e., overeducated workers earn less and undereducated workers earn more than equally educated workers who are employed in occupations which fully utilize their education.

$5 \quad$ See Hsiao (1986) and Baltagi (1995) for surveys of panel data estimation techniques. 
Accounting for unobserved heterogeneity changes the above picture dramatically. Lagrange multiplier tests for random effects (Breusch and Pagan, 1980) favors the random effects model over the pooled OLS and Hausman specifications tests (Hausman, 1978) show that the random effects model could be rejected against the fixed effects model for all specifications. Note however, that the estimated coefficients for the used schooling variables should be interpreted with care, since the low within variation of these variables (see Table 2) cause doubts that the effects of these variables could be identified.

For all sub-samples, the absolute values of the estimated coefficients on the dummies indicating educational mismatch are significantly lower in the random effects model compared to the pooled OLS. The undereducation dummies for the total and the male sample become even statistically insignificant when using the mean-index. Except for undereducated females, which experience an earnings disadvantage of $2.1 \%$ when using the mode-index, all coefficients on the over- and undereducation dummies become statistically insignificant in the fixed effects model. In contrast to the results of the pooled OLS regression, the results for the panel estimates suggest that the returns to schooling are determined independently from the occupation an individual performs. The results for the panel estimates further indicate the importance to control for unobserved heterogeneity when estimating the Verdugo-Verdugo model.

Table 4 reports the estimation results for equation (4) and (5). Concentrating first on the estimation results obtained by pooled OLS for the total sample it appears that the returns to actual years of schooling is about $5.8 \%$ and that males display higher returns than females. These results are similar to those obtained in other German studies using the same data set (Haisken-DeNew and Schmidt, 1999). The returns to required schooling are significantly higher than the returns to actual years of schooling, especially when using the mean-index. The returns to required schooling are $7.9 \%$ when using the meanindex and $6.4 \%$ when using the mode index. Males receive lower returns to required schooling than females when using the mean-index. Based on the mode-index, however, the returns to required schooling do not vary with gender.

For the pooled OLS, all coefficients of the years of over- and underschooling are statistically significant and have the expected sign, with the exception of the coefficent on 
years of overschooling, which is insignificant for females when using the mean-index. Using the mean-index, the returns to a year of overeducation is $10.5 \%$ for males and significantly larger than the returns to an additional year of required schooling. Note, however, that the returns to a year of overschooling for males drops to $6.2 \%$ and that the difference between the returns to overschooling and required schooling becomes insignificant when using the mode-index. For females the returns to a year of overschooling is insignificant when using the mean-index and $2.4 \%$ when using the mode-index. The latter is significantly lower than the returns to an additional year of required schooling. Undereducated workers earn significantly less than adequately educated workers for all sub-samples. Note, that the absolute value of the estimated coefficient on years of underschooling is significantly lower when using the mode-index. For males the returns to a year of undereducation are $-5.6 \%$ when using the mean-index and $-2.3 \%$ when using the mode-index; for females the respective returns are $-10.7 \%$ and $-3.6 \%$. Overall these results imply, that adequately educated and overeducated male workers receive about the same returns to schooling, while overeducated females receive lower returns for an additional year of schooling than adequately educated females. Undereducated workers, in particular undereducated females, earn consistently less than adequately educated workers.

Table 4 also provides the values of F-tests for the prediction of the human capital model that the years of adequate-, over- und undereducation should be rewarded equally, i.e. $\beta_{1}=\beta_{2}=-\beta_{3}$, and for the prediction of the job competition model that only adequate schooling is rewarded, i.e. $\beta_{2}=\beta_{3}=0$. The F-test for the pooled OLS results shows that the human capital hypothesis of equal returns on adequate-, over-, and underschooling could be rejected at the $1 \%$ level for all specifications except for the full sample when using the mean-index and for females, where the hypothesis could be rejected only at the $10 \%$ level when using the mean-index. The F-tests on the validity of the job competition model could be strongly rejected at the $1 \%$ level for both measures of educational matching and all sub-samples.

Similar to the results for the Verdugo and Verdugo model, the estimation results change when accounting for unobserved heterogeneity. For all specifications, Hausman specification tests and Lagrange multiplier tests indicate that the random effects model is 
rejected against the fixed effects model and that the pooled OLS is rejected against the random effects model. As already noted, the estimation results for the fixed effects model when using the mean-index should be interpreted with care because of the small within group variation of the variables used on required schooling and over- and undereducation. Apart from the random effects model for both indices, only the results of the fixed effects model using the mode-index are therefore discussed here.

For both the random and fixed effects model, the difference between the returns to actual years of schooling and the return to required schooling becomes smaller if compared to the results of the pooled OLS. The estimated coefficients on years of overeducation drop in absolute size for the total and the male sample and rise for the female sample, whereas the absolute value for the rate of return of underschooling increases in all cases for the random effects model. Furthermore, the differences between the returns to a year of required schooling and the returns to a year of overschooling becomes smaller and in most cases even insignificant. ${ }^{6}$ For the random effects model on the basis of the mean-index and the fixed effects model when using the mode-index the human capital hypothesis of equal returns to adequate-, over-, and underschooling could not be rejected at least at a 5\% level. In the random effects model using the mode index, the human capital assumption could be strongly rejected for the males, but not for the females. Similar to the pooled OLS, the job competition model could be rejected for all specification and sub-samples for both the random effects and the fixed effects model.

One might argue, that the indexes used for defining educational mismatch, especially the mode-index, might be biased due to the occurrence of small cell sizes within 3-digit occupations. Therefore, all estimations were repeated using the two indexes calculated on a 2-digit occupational level. At this level there are much larger cell sizes within occupations and results should be less affected by the occupational mobility of individuals. We further estimated all the specifications on a restricted sample, where

\footnotetext{
F-tests on the hypothesis that $\beta_{1}-\beta_{2}=0$, which are not reported here, could not be rejected at least at a 5\%-level for all sub-samples in the random-effects model when using the mean-index and for the total sample and the female sub-sample in the fixed effects model when using the mode-index. For the male sub-sample the hypothesis could not be rejected at the $10 \%$-level in the fixed effects model.
} 
occupations with less than 70 observations within each occupation were excluded. The estimation results reported above are very robust to these changes. ${ }^{7}$

\section{Conclusion}

This paper provides an empirical evaluation of the wage effects of over- und undereducation using a German panel data set. In particular, the paper investigates the to control for unobserved heterogeneity when estimating the wage effects of educational mismatch. The empirical analysis of the paper uses two different measures of educational mismatch, drawn from previous literature. The first measure defines required education as a one-standard-deviation range around the mean schooling level in 3-digit occupations. The second measure defines required schooling as the modal value of years of schooling in 3-digit occupations. Both measures indicate, that educational mismatch in Germany increased slightly between 1985 and 1995, particularly for females. The two measures, however, give a different picture of the level of educational mismatch. Whereas the mean-index implies that the majority of West German workers is adequately educated for the jobs they perform, the mode-index shows that about $50 \%$ of the employees are either over- or undereducated.

The results of the effects of educational mismatch on wages using pooled OLS estimation are broadly in line with the existing literature. Overeducated workers earn less and undereducated workers earn more than workers with the same level of educational attainment, but who work in occupations which fully utilize their education. Compared to co-workers in the same occupation who are adequately educated, overeducated workers earn more and undereducated workers receive less. The rate of return to a year of schooling required for a job and the rate of return to a year of overeducation are similar for males, whereas females receive lower returns to a year of overeducation than to a year of required schooling. The rates of return to a year of undereducation are consistently negative for both measures of educational mismatch and for all sub-samples. Finally, the estimation results for the pooled OLS imply that both, the human capital model, which

The estimation results using the two indexes based on 2-digit occupations and the restricted sample are available on request. 
assumes equal rate of returns to adequate-, over-, and underschooling, and the job competition model, which assumes that there are no returns on over- and underschooling, could be strongly rejected.

The estimated effects change dramatically when one controls for unobserved heterogeneity by using panel estimation techniques. The earnings differences between inadequately educated workers and equally educated workers who work in occupations for which they are adequately educated become statistically insignificant when controlling for unobserved heterogeneity. The absolute value of the rates of return to years of overschooling becomes similar to the rates of return to required schooling, and the rates of return to a year of underschooling becomes more negative. Similar to the results for the pooled OLS, the job competition model could be strongly rejected when using panel estimators. When controlling for unobserved heterogeneity, however, the assumptions of the human capital model could no longer be rejected. The results of this paper indicate the need to test whether existing results on the labor market effects of educational mismatch for various countries change, when the importance of unobserved individual effects is taken into account. 


\section{REFERENCES}

Alba-Ramirez, A. (1992): "Mismatch in the Spanish Labor Market: Overeducation," Journal of Human Resources, 26. 259-278.

Baltagi, B. H. (1995): Econometric Analysis of Panel Data. New York: John Wiley.

Breusch, T. and A. Pagan (1980): "The LM Test and Its Applications to Model Specification in Econometrics," Review of Economics Studies, 47, 239-254.

Cohn, E. and S. P. Kahn (1995): "The Wage Effects of Overschooling Revisited," Labour Economics, 2, 67-76.

Duncan, G. J. and S. D. Hoffman (1981): "The Incidence and Wage Effects of Overeducation," Economics of Education Review, 1(1), 75-86.

Groot, W. (1993): "Overeducation and the Returns to Enterprise-related Schooling," Economics of Education Review, 12(4), 299-309.

Groot, W. (1996): "The Incidence of, and Returns to Overeducation in the UK," Applied Economics, 28, 1345-1350.

Haisken-DeNew, J. P. and C. M. Schmidt (1999): "Money for Nothing and Your Chips for Free? The Anatomy of the PC Wage Differential," DIW Discussion Papers no. 178, Berlin.

Hartog, J. and H. Oosterbeek (1988): "Education, Allocation and Earnings in the Netherlands: Overschooling?," Economics of Education Review, 7(2), 185-194.

Hausman, J. (1978): "Specification Tests in Econometrics," Econometrica, 46, 12511271.

Hersch, J. (1991): "Education Match and Job Match," Review of Economics and Statistics, 73, 140-144.

Hsiao, C. (1986): Analysis of Panel Data. New York: Cambridge University Press.

Kiker, B. F., M. C. Santos and M. M. de Oliveira (1997): "Overeducation and Undereducation: Evidence for Portugal," Economics of Education Review, 16(2), 111-125.

McGoldrick, K.M. and J. Robst (1996): "Gender Differences in Overeducation: A Test of the Theory of Differential Overqualification," American Economic Review, 86(2), 280-284.

Mincer, A. (1974): Schooling, Experience and Earnings. New York: NBER.

Rumberger, R. W. (1987): "The Impact of Surplus Schooling on Productivity and Earning," Journal of Human Resources, 22(1), 1-50.

Robst, J. (1995a): "Career Mobility, Job Match, and Overeducation," Eastern Economic Journal, 21(4), 539-550.

Robst, J. (1995b): "College Quality and Overeducation," Economics of Education Review, 14(3), 221-228.

Sicherman, N. (1991): "Overeducation in the Labor Market," Journal of Labor Economics, 9(2), 101-122.

Sloane, P. J., H. Battu and P. T. Seaman (1999): "Overeducation, Undereducation and the British Labour Market," Applied Economics, 31, 1437-1453.

Thurow, L. C. (1975): Generating Inequality. New York: Basic Books.

Tsang, M. C., R. W. Rumberger, and H. M. Levin (1991): "The Impact of Surplus Schooling on Worker Productivity," Industrial Relations, 30(2), 209-228. 
Verdugo, R. and N. Verdugo (1989): "The Impact of Surplus Schooling on Earnings: Some Additional Findings," Journal of Human Resources, 24, 629-643. 
Table 1: The incidence of over-and undereducation by gender*

\begin{tabular}{|c|c|c|c|c|c|c|c|c|c|}
\hline & \multicolumn{3}{|c|}{ Total } & \multicolumn{3}{|c|}{ Male } & \multicolumn{3}{|c|}{ Female } \\
\hline & 1985 & 1990 & 1995 & 1985 & 1990 & 1995 & 1985 & 1990 & 1995 \\
\hline Years of Schooling & $\begin{array}{c}11.96 \\
(0.08)\end{array}$ & $\begin{array}{l}11.97 \\
(0.09)\end{array}$ & $\begin{array}{c}12.17 \\
(0.12)\end{array}$ & $\begin{array}{c}11.99 \\
(0.09)\end{array}$ & $\begin{array}{l}11.99 \\
(0.10)\end{array}$ & $\begin{array}{l}12.17 \\
(0.12)\end{array}$ & $\begin{array}{l}11.85 \\
(0.15)\end{array}$ & $\begin{array}{l}11.91 \\
(0.19)\end{array}$ & $\begin{array}{l}12.19 \\
(0.31)\end{array}$ \\
\hline
\end{tabular}

\begin{tabular}{|c|c|c|c|c|c|c|c|c|c|}
\hline \multicolumn{10}{|c|}{ Mean-Index } \\
\hline $\begin{array}{l}\text { Years of Required } \\
\text { Schooling }\end{array}$ & $\begin{array}{l}11.94 \\
(0.06)\end{array}$ & $\begin{array}{l}11.88 \\
(0.07)\end{array}$ & $\begin{array}{l}12.12 \\
(0.09)\end{array}$ & $\begin{array}{l}11.92 \\
(0.07)\end{array}$ & $\begin{array}{l}11.88 \\
(0.08)\end{array}$ & $\begin{array}{l}12.16 \\
(0.10)\end{array}$ & $\begin{array}{l}12.01 \\
(0.12)\end{array}$ & $\begin{array}{l}11.87 \\
(0.12)\end{array}$ & $\begin{array}{l}12.03 \\
(0.18)\end{array}$ \\
\hline $\begin{array}{l}\text { Years of } \\
\text { Overeducation }\end{array}$ & $\begin{array}{c}0.12 \\
(0.01)\end{array}$ & $\begin{array}{c}0.16 \\
(0.02)\end{array}$ & $\begin{array}{c}0.17 \\
(0.05)\end{array}$ & $\begin{array}{c}0.13 \\
(0.02)\end{array}$ & $\begin{array}{c}0.16 \\
(0.02)\end{array}$ & $\begin{array}{c}0.14 \\
(0.02)\end{array}$ & $\begin{array}{c}0.09 \\
(0.02)\end{array}$ & $\begin{array}{c}0.18 \\
(0.05)\end{array}$ & $\begin{array}{c}0.26 \\
(0.17)\end{array}$ \\
\hline $\begin{array}{l}\text { Years of } \\
\text { Undereducation }\end{array}$ & $\begin{array}{c}0.06 \\
(0.01)\end{array}$ & $\begin{array}{c}0.07 \\
(0.01)\end{array}$ & $\begin{array}{c}0.08 \\
(0.01)\end{array}$ & $\begin{array}{c}0.06 \\
(0.01)\end{array}$ & $\begin{array}{c}0.07 \\
(0.01)\end{array}$ & $\begin{array}{c}0.08 \\
(0.02)\end{array}$ & $\begin{array}{c}0.08 \\
(0.02)\end{array}$ & $\begin{array}{c}0.08 \\
(0.02)\end{array}$ & $\begin{array}{c}0.06 \\
(0.01)\end{array}$ \\
\hline Overeducated & 0.11 & 0.13 & 0.13 & 0.12 & 0.13 & 0.12 & 0.09 & 0.13 & 0.16 \\
\hline Undereducated & 0.09 & 0.10 & 0.10 & 0.08 & 0.09 & 0.09 & 0.13 & 0.13 & 0.12 \\
\hline \multicolumn{10}{|c|}{ Mode-Index } \\
\hline $\begin{array}{l}\text { Years of Required } \\
\text { Schooling }\end{array}$ & $\begin{array}{l}11.97 \\
(0.08)\end{array}$ & $\begin{array}{l}11.98 \\
(0.09)\end{array}$ & $\begin{array}{l}12.27 \\
(0.12)\end{array}$ & $\begin{array}{l}11.93 \\
(0.09)\end{array}$ & $\begin{array}{l}12.07 \\
(0.10)\end{array}$ & $\begin{array}{l}12.31 \\
(0.13)\end{array}$ & $\begin{array}{l}12.09 \\
(0.16)\end{array}$ & $\begin{array}{l}11.72 \\
(0.16)\end{array}$ & $\begin{array}{l}12.15 \\
(0.28)\end{array}$ \\
\hline $\begin{array}{l}\text { Years of } \\
\text { Overeducation }\end{array}$ & $\begin{array}{c}0.46 \\
(0.03)\end{array}$ & $\begin{array}{c}0.55 \\
(0.05)\end{array}$ & $\begin{array}{c}0.55 \\
(0.07)\end{array}$ & $\begin{array}{c}0.48 \\
(0.04)\end{array}$ & $\begin{array}{c}0.49 \\
(0.05)\end{array}$ & $\begin{array}{c}0.51 \\
(0.05)\end{array}$ & $\begin{array}{c}0.42 \\
(0.06)\end{array}$ & $\begin{array}{c}0.74 \\
(0.13)\end{array}$ & $\begin{array}{c}0.66 \\
(0.21)\end{array}$ \\
\hline $\begin{array}{l}\text { Years of } \\
\text { Undereducation }\end{array}$ & $\begin{array}{c}0.47 \\
(0.03)\end{array}$ & $\begin{array}{c}0.56 \\
(0.04)\end{array}$ & $\begin{array}{c}0.64 \\
(0.06)\end{array}$ & $\begin{array}{c}0.41 \\
(0.04)\end{array}$ & $\begin{array}{c}0.56 \\
(0.05)\end{array}$ & $\begin{array}{c}0.65 \\
(0.07)\end{array}$ & $\begin{array}{c}0.67 \\
(0.08)\end{array}$ & $\begin{array}{c}0.55 \\
(0.07)\end{array}$ & $\begin{array}{c}0.62 \\
(0.11)\end{array}$ \\
\hline Overeducated & 0.25 & 0.25 & 0.25 & 0.26 & 0.24 & 0.25 & 0.23 & 0.27 & 0.24 \\
\hline Undereducated & 0.23 & 0.23 & 0.25 & 0.19 & 0.22 & 0.24 & 0.35 & 0.28 & 0.30 \\
\hline Observations & 1,739 & 1,386 & 1,105 & 1,340 & 1,062 & 846 & 399 & 324 & 259 \\
\hline
\end{tabular}

*: All numbers are weighted. Standard deviations in parentheses. 
Table 2: Summary Statistics*

\begin{tabular}{|c|c|c|c|}
\hline & Total & Male & Female \\
\hline $\log$ (wage) & $\begin{array}{c}3.095 \\
(0.44)[0.38]\{0.26\}\end{array}$ & $\begin{array}{c}3.148 \\
(0.42)[0.35]\{0.27\}\end{array}$ & $\begin{array}{c}3.148 \\
(0.42)[0.35]\{0.27\}\end{array}$ \\
\hline Years of Schooling & $\begin{array}{c}11.897 \\
(2.59)[2.57]\{0.23\}\end{array}$ & $\begin{array}{c}11.956 \\
(2.62)[2.61]\{0.23\}\end{array}$ & $\begin{array}{c}11.703 \\
(2.50)[2.48]\{0.22\}\end{array}$ \\
\hline \multicolumn{4}{|l|}{ Mean-Index: } \\
\hline Years of Required Schooling & $\begin{array}{c}11.900 \\
(2.03)[1.96]\{0.55\}\end{array}$ & $\begin{array}{c}11.906 \\
(2.07)[2.02]\{0.56\}\end{array}$ & $\begin{array}{c}11.880 \\
(1.89)[1.82]\{0.50\}\end{array}$ \\
\hline Years of Overeducation & $\begin{array}{c}0.135 \\
(0.54)[0.48]\{0.25\}\end{array}$ & $\begin{array}{c}0.142 \\
(0.56)[0.49]\{0.26\}\end{array}$ & $\begin{array}{c}0.115 \\
(0.49)[0.48]\{0.18\}\end{array}$ \\
\hline Years of Undereducation & $\begin{array}{c}0.074 \\
(0.33)[0.31]\{0.15\}\end{array}$ & $\begin{array}{c}0.068 \\
(0.33)[0.32]\{0.14\}\end{array}$ & $\begin{array}{c}0.093 \\
(0.33)[0.30]\{0.17\}\end{array}$ \\
\hline Overeducated & 0.120 & 0.126 & 0.100 \\
\hline Undereducated & 0.103 & 0.091 & 0.144 \\
\hline \multicolumn{4}{|l|}{ Mode-Index: } \\
\hline Years of Required Schooling & $\begin{array}{c}12.005 \\
(2.62)[2.42]\{1.10\}\end{array}$ & $\begin{array}{c}12.028 \\
(2.68)[2.46]\{1.15\}\end{array}$ & $\begin{array}{c}11.930 \\
(2.44)[2.29]\{0.91\}\end{array}$ \\
\hline Years of Overeducation & $\begin{array}{c}0.467 \\
(1.22)[1.05]\{0.63\}\end{array}$ & $\begin{array}{c}0.471 \\
(1.25)[1.06]\{0.66\}\end{array}$ & $\begin{array}{c}0.452 \\
(1.14)[1.02]\{0.53\}\end{array}$ \\
\hline Years of Undereducation & $\begin{array}{c}0.574 \\
(1.40)[1.21]\{0.84\}\end{array}$ & $\begin{array}{c}0.542 \\
(1.42)[1.22]\{0.88\}\end{array}$ & $\begin{array}{c}0.678 \\
(1.34)[1.20]\{0.69\}\end{array}$ \\
\hline Overeducated & 0.240 & 0.242 & 0.236 \\
\hline Undereducated & 0.246 & 0.217 & 0.340 \\
\hline Number of Individuals & 2,945 & 2,089 & 856 \\
\hline Number of Observations & 18,647 & 14,265 & 4,382 \\
\hline
\end{tabular}

*: $\quad(\ldots)$ : overall standard deviation; $[\ldots]$ between standard deviation; $\{\ldots\}$ within standard deviation. 
Table 3: Estimated earnings functions: Verdugo and Verdugo-model*

\begin{tabular}{|c|c|c|c|c|c|c|}
\hline & \multicolumn{2}{|c|}{ Pooled OLS } & \multicolumn{2}{|c|}{ Random Effects } & \multicolumn{2}{|c|}{ Fixed Effects } \\
\hline & Mean & Mode & Mean & Mode & Mean & Mode \\
\hline \multicolumn{7}{|c|}{ Total Sample: } \\
\hline \multirow[t]{2}{*}{ Years of Schooling } & $0.063^{t+}$ & $0.064^{\dagger t}$ & $0.053^{t+}$ & $0.053^{+\dagger}$ & $0.025^{t+}$ & $0.025^{t+}$ \\
\hline & $(0.002)$ & $(0.002)$ & $(0.002)$ & $(0.002)$ & $(0.005)$ & $(0.005)$ \\
\hline \multirow[t]{2}{*}{ Overeducated } & $-0.048^{t \dagger}$ & -0.001 & $-0.017^{\dagger \dagger}$ & $-0.009^{\dagger}$ & -0.005 & -0.008 \\
\hline & $(0.014)$ & $(0.010)$ & $(0.007)$ & $(0.005)$ & $(0.007)$ & $(0.006)$ \\
\hline \multirow[t]{2}{*}{ Undereducated } & $0.050^{t \dagger}$ & $0.106^{\dagger \dagger}$ & 0.007 & $0.015^{\dagger \dagger}$ & -0.004 & -0.005 \\
\hline & $(0.014)$ & $(0.010)$ & $(0.006)$ & $(0.005)$ & $(0.007)$ & $(0.005)$ \\
\hline $\mathrm{R}^{2}$ & 0.62 & 0.63 & 0.61 & 0.61 & 0.08 & 0.08 \\
\hline \multicolumn{7}{|c|}{ Males: } \\
\hline \multirow[t]{2}{*}{ Years of Schooling } & $0.064^{\dagger+}$ & $0.066^{+\dagger}$ & $0.054^{\dagger+}$ & $0.054^{\dagger \dagger}$ & $0.024^{+\dagger}$ & $0.025^{+\dagger}$ \\
\hline & $(0.003)$ & $(0.003)$ & $(0.002)$ & $(0.002)$ & $(0.005)$ & $(0.005)$ \\
\hline \multirow[t]{2}{*}{ Overeducated } & -0.026 & 0.010 & -0.011 & -0.004 & -0.005 & -0.004 \\
\hline & $(0.016)$ & $(0.011)$ & $(0.007)$ & $(0.006)$ & $(0.008)$ & $(0.006)$ \\
\hline \multirow{2}{*}{ Undereducated } & $0.072^{+\dagger}$ & $0.118^{t \dagger}$ & 0.010 & $0.022^{\dagger \dagger}$ & -0.005 & 0.001 \\
\hline & $(0.016)$ & $(0.012)$ & $(0.008)$ & $(0.006)$ & $(0.008)$ & $(0.006)$ \\
\hline \multirow[t]{2}{*}{$\mathrm{R}^{2}$} & 0.62 & 0.63 & 0.60 & 0.61 & 0.08 & 0.08 \\
\hline & & & es: & & & \\
\hline \multirow[t]{2}{*}{ Years of Schooling } & $0.060^{\dagger \dagger}$ & $0.059^{+\dagger}$ & $0.055^{\dagger \dagger}$ & $0.053^{\dagger \dagger}$ & $0.031^{\dagger \dagger}$ & $0.028^{\dagger \dagger}$ \\
\hline & $(0.004)$ & $(0.004)$ & $(0.004)$ & $(0.004)$ & $(0.010)$ & $(0.010)$ \\
\hline \multirow[t]{2}{*}{ Overeducated } & $-0.154^{t+}$ & $-0.053^{t+}$ & $-0.042^{t+}$ & $-0.023^{t+}$ & -0.009 & -0.017 \\
\hline & $(0.030)$ & $(0.022)$ & $(0.015)$ & $(0.011)$ & $(0.016)$ & $(0.012)$ \\
\hline \multirow[t]{2}{*}{ Undereducated } & 0.008 & $0.060^{\dagger+}$ & 0.003 & -0.001 & -0.002 & $-0.021^{\dagger \dagger}$ \\
\hline & $(0.023)$ & $(0.020)$ & $(0.012)$ & $(0.010)$ & $(0.012)$ & $(0.010)$ \\
\hline $\mathrm{R}^{2}$ & 0.58 & 0.58 & 0.56 & 0.55 & 0.04 & 0.04 \\
\hline
\end{tabular}

*: $\quad$ Standard errors in parentheses. ${ }^{\dagger}:$ statistically significant at least at the 10 percent level. ${ }^{\dagger+}$ : statistically significant at least at the 5 percent level. All regressions include the variables age and age squared, tenure and tenure squared, a dummy for marital status, three dummies for firm size, two dummies for region, five dummies for industry and year dummies. Total sample: 18647 observations of 2945 individuals; Male sample: 14265 observations of 2089 individuals; Female sample: 4382 observations of 856 individuals. Breusch and Pagan (1980) Lagrangian multiplier test statistics for random effects have been significant at least at the 1 percent level for all specifications. Hausman tests on the hypothesis that the coefficients in the random effects model and the fixed effects model are the same could be rejected for all specifications at least at the 1 percent level. 
Table 4: Estimated earnings functions: Duncan and Hoffman model*

\begin{tabular}{|c|c|c|c|c|c|c|}
\hline & \multicolumn{2}{|c|}{ Pooled OLS } & \multicolumn{2}{|c|}{ "Random Effects } & \multicolumn{2}{|c|}{ Fixed Effects } \\
\hline & Mean & Mode & Mean & Mode & Mean & Mode \\
\hline \multicolumn{7}{|c|}{ Total Sample: } \\
\hline Years of Schooling & \multirow{2}{*}{\multicolumn{2}{|c|}{$\begin{array}{l}0.058^{\dagger \dagger} \\
(0.002)\end{array}$}} & \multirow{2}{*}{\multicolumn{2}{|c|}{$\begin{array}{l}0.052^{\dagger \dagger} \\
(0.002)\end{array}$}} & \multicolumn{2}{|c|}{$0.025^{\dagger \dagger}$} \\
\hline & & & & & & \\
\hline $\mathrm{R}^{2}$ & \multicolumn{2}{|c|}{0.66} & \multicolumn{2}{|c|}{0.63} & \multicolumn{2}{|c|}{0.08} \\
\hline Years of Required & $0.079^{\dagger \dagger}$ & $0.064^{\dagger+}$ & $0.045^{+\dagger}$ & $0.055^{\dagger \dagger}$ & $0.006^{\dagger \dagger}$ & $0.027^{\dagger+}$ \\
\hline Schooling & $(0.003)$ & $(0.002)$ & $(0.002)$ & $(0.002)$ & $(0.002)$ & $(0.005)$ \\
\hline \multirow[t]{2}{*}{ Years overeducated } & $0.086^{\dagger \dagger}$ & $0.055^{t \dagger}$ & $0.047^{\dagger \dagger}$ & $0.049^{t \dagger}$ & 0.003 & $0.023^{\dagger \dagger}$ \\
\hline & $(0.012)$ & $(0.004)$ & $(0.004)$ & $(0.002)$ & $(0.005)$ & $(0.005)$ \\
\hline \multirow[t]{2}{*}{ Years undereducated } & $-0.069^{t \dagger}$ & $-0.025^{t+}$ & $-0.059^{t+}$ & $-0.047^{\dagger \dagger}$ & $-0.015^{\dagger}$ & $-0.026^{t+}$ \\
\hline & $(0.013)$ & $(0.004)$ & $(0.007)$ & $(0.002)$ & $(0.008)$ & $(0.005)$ \\
\hline $\mathrm{R}^{2}$ & 0.64 & 0.64 & 0.60 & 0.61 & 0.06 & 0.08 \\
\hline$\beta_{1}=\beta_{2}=-\beta_{3}$ & 0.50 & $93.27^{\dagger \dagger}$ & $4.75^{\dagger}$ & $49.37^{\dagger \dagger}$ & 1.07 & 2.20 \\
\hline$\beta_{2}=\beta_{3}=0$ & $43.60^{\dagger \dagger}$ & $134.11^{\dagger \dagger}$ & $182.00^{\dagger \dagger}$ & $706.09^{\dagger \dagger}$ & 1.80 & $14.31^{\dagger \dagger}$ \\
\hline \multicolumn{7}{|c|}{ Males: } \\
\hline Years of Schooling & \multirow{2}{*}{\multicolumn{2}{|c|}{$\begin{array}{l}0.060^{\dagger \dagger} \\
(0.002)\end{array}$}} & \multirow{2}{*}{\multicolumn{2}{|c|}{$\begin{array}{l}0.052^{\dagger \dagger} \\
(0.002)\end{array}$}} & \multirow{2}{*}{\multicolumn{2}{|c|}{$\begin{array}{l}0.024^{\dagger \dagger} \\
(0.005)\end{array}$}} \\
\hline & & & & & & \\
\hline $\mathrm{R}^{2}$ & \multicolumn{2}{|c|}{0.66} & \multicolumn{2}{|c|}{0.63} & \multicolumn{2}{|c|}{0.07} \\
\hline Years of Required & $0.078^{+\dagger}$ & $0.065^{+\dagger}$ & $0.045^{+\dagger}$ & $0.055^{+\dagger}$ & $0.008^{+\dagger}$ & $0.026^{+\dagger}$ \\
\hline Schooling & $(0.003)$ & $(0.003)$ & $(0.002)$ & $(0.002)$ & $(0.003)$ & $(0.005)$ \\
\hline \multirow[t]{2}{*}{ Years overeducated } & $0.105^{t \dagger}$ & $0.062^{+\dagger}$ & $0.050^{\dagger t}$ & $0.050^{t+}$ & 0.003 & $0.023^{t+}$ \\
\hline & $(0.009)$ & $(0.003)$ & $(0.005)$ & $(0.002)$ & $(0.005)$ & $(0.006)$ \\
\hline \multirow{2}{*}{ Years undereducated } & $-0.056^{+t}$ & $-0.023^{t+}$ & $-0.062^{+t}$ & $-0.047^{t+}$ & $-0.021^{t+}$ & $-0.024^{t+}$ \\
\hline & $(0.015)$ & $(0.004)$ & $(0.008)$ & $(0.002)$ & $(0.010)$ & $(0.005)$ \\
\hline $\mathrm{R}^{2}$ & 0.63 & 0.64 & 0.60 & 0.61 & 0.07 & $3.19^{t+}$ \\
\hline$\beta_{1}=\beta_{2}=-\beta_{3}$ & $4.86^{\dagger \dagger}$ & $78.65^{\dagger+}$ & $5.47^{\dagger}$ & $49.44^{\dagger \dagger}$ & 1.54 & 1.26 \\
\hline$\beta_{2}=\beta_{3}=0$ & $72.03^{+\dagger}$ & $171.36^{\dagger \dagger}$ & $162.79^{\dagger \dagger}$ & $569.29^{\dagger \dagger}$ & $2.35^{\dagger}$ & $10.03^{\dagger+}$ \\
\hline \multicolumn{7}{|c|}{ Females: } \\
\hline Years of Schooling & \multirow{2}{*}{\multicolumn{2}{|c|}{$\begin{array}{l}0.051^{\dagger \dagger} \\
(0.004)\end{array}$}} & \multirow{2}{*}{\multicolumn{2}{|c|}{$\begin{array}{l}0.052^{\dagger \dagger} \\
(0.004)\end{array}$}} & & \\
\hline & & & & & & \\
\hline $\mathrm{R}^{2}$ & & & & & & \\
\hline Years of Required & $0.083^{+\dagger}$ & $0.063^{+\dagger}$ & $0.047^{\dagger+}$ & $0.054^{+\dagger}$ & -0.001 & $0.028^{\dagger+}$ \\
\hline Schooling & $(0.005)$ & $(0.004)$ & $(0.004)$ & $(0.004)$ & $(0.005)$ & $(0.010)$ \\
\hline Years overeducated & 0.007 & $0.024^{t+}$ & $0.041^{\dagger t}$ & $0.047^{+\dagger}$ & 0.008 & $0.028^{\dagger \dagger}$ \\
\hline & $(0.037)$ & $(0.011)$ & $(0.011)$ & $(0.005)$ & $(0.013)$ & $(0.011)$ \\
\hline Years undereducated & $-0.107^{\dagger \dagger}$ & $-0.036^{\dagger \dagger}$ & $-0.050^{\dagger \dagger}$ & $-0.051^{+\dagger}$ & 0.002 & $-0.031^{\dagger \dagger}$ \\
\hline & $(0.018)$ & $(0.007)$ & $(0.013)$ & $(0.004)$ & $(0.014)$ & $(0.010)$ \\
\hline $\mathrm{R}^{2}$ & 0.61 & 0.59 & 0.56 & 0.56 & 0.03 & 0.04 \\
\hline$\beta_{1}=\beta_{2}=-\beta_{3}$ & $2.74^{\dagger}$ & $18.36^{\dagger \dagger}$ & 0.37 & $5.04^{\dagger}$ & 0.24 & 0.62 \\
\hline$\beta_{2}=\beta_{3}=0$ & $18.50^{\dagger \dagger}$ & $17.83^{\dagger \dagger}$ & $29.46^{\dagger \dagger}$ & $169.32^{\dagger \dagger}$ & 0.19 & $4.79^{\dagger+}$ \\
\hline $\begin{array}{l}\text { Standard errors in } \\
\text { significant at least } \\
\text { tenure and tenure s } \\
\text { region, five dumm } \\
\text { individuals; Male s } \\
\text { of } 856 \text { individuals. } \\
\text { have been signific } \\
\text { hypothesis that the }\end{array}$ & $\begin{array}{l}\text { theses. }{ }^{\dagger} \text { : } \\
\text { he } 5 \text { perce } \\
\text { red, a dum } \\
\text { for indust } \\
\text { le: } 14265 \\
\text { usch and I } \\
\text { at least at } \\
\text { fficients in }\end{array}$ & $\begin{array}{l}\text { istically } \\
\text { level. All } \\
\text { for marita } \\
\text { and year } \\
\text { ervations } \\
\text { an (1980) } \\
\text { e } 1 \text { perce }\end{array}$ & $\begin{array}{l}\text { ificant at l } \\
\text { ressions in } \\
\text { tatus, three } \\
\text { mmies. To } \\
2089 \text { indiv } \\
\text { grangian n } \\
\text { level for }\end{array}$ & $\begin{array}{l}\text { t at the } 10 \\
\text { ude the va } \\
\text { ummies fo } \\
\text { sample: } \\
\text { dals; Fema } \\
\text { Itiplier test } \\
\text { specificat }\end{array}$ & $\begin{array}{l}\text { cent level } \\
\text { les age a } \\
\text { rm size, t } \\
47 \text { obser } \\
\text { ample: } 43 \\
\text { tistics for } \\
\text { s. Hausm }\end{array}$ & $\begin{array}{l}\text { statistica } \\
\text { age squar } \\
\text { dummies } \\
\text { ons of } 29 \\
\text { observatio } \\
\text { dom effe } \\
\text { tests on t }\end{array}$ \\
\hline
\end{tabular}


Appendix Table 1 (NOT intended for publication): Estimation Results based on Total Sample

\begin{tabular}{|c|c|c|c|c|c|c|c|c|c|c|c|c|c|c|c|}
\hline & \multicolumn{9}{|c|}{ Mean-Index } & \multicolumn{6}{|c|}{$\begin{array}{l}\text { Mode-Index } \\
\end{array}$} \\
\hline & \multirow[b]{2}{*}{ Pooled } & \multicolumn{2}{|c|}{ Iuman Capital } & \multicolumn{3}{|c|}{ Duncan and Hoffman } & \multicolumn{3}{|c|}{ Verdugo and Verdugo } & \multicolumn{3}{|c|}{ Duncan and Hoffman } & \multicolumn{3}{|c|}{ Verdugo and Verdugo } \\
\hline & & $\begin{array}{c}\text { Random } \\
\text { Effects }\end{array}$ & $\begin{array}{c}\text { Fixed } \\
\text { Effects }\end{array}$ & Pooled & $\begin{array}{c}\text { Random } \\
\text { Effects }\end{array}$ & $\begin{array}{c}\text { Fixed } \\
\text { Effects }\end{array}$ & Pooled & $\begin{array}{c}\text { Random } \\
\text { Effects }\end{array}$ & $\begin{array}{c}\text { Fixed } \\
\text { Effects }\end{array}$ & Pooled & $\begin{array}{c}\text { Random } \\
\text { Effects }\end{array}$ & $\begin{array}{c}\text { Fixed } \\
\text { Effects }\end{array}$ & Pooled & $\begin{array}{c}\text { Random } \\
\text { Effects }\end{array}$ & $\begin{array}{c}\text { Fixed } \\
\text { Effects }\end{array}$ \\
\hline Years of Schooling & $\begin{array}{l}0.058^{++} \\
(0.002)\end{array}$ & $\begin{array}{l}0.052^{++} \\
(0.002)\end{array}$ & $\begin{array}{l}0.025^{+\dagger} \\
(0.005)\end{array}$ & - & & & $\begin{array}{l}0.063^{++} \\
(0.002)\end{array}$ & $\begin{array}{l}0.054^{++} \\
(0.002)\end{array}$ & $\begin{array}{l}0.025^{++} \\
(0.005)\end{array}$ & - & - & & $\begin{array}{l}0.064^{++} \\
(0.002)\end{array}$ & $\begin{array}{l}0.054^{++} \\
(0.002)\end{array}$ & $\begin{array}{l}0.025^{++} \\
(0.005)\end{array}$ \\
\hline Required Schooling & - & - & 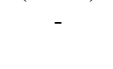 & $\begin{array}{l}0.079^{++} \\
(0.003)\end{array}$ & $\begin{array}{l}0.045^{++} \\
(0.002)\end{array}$ & $\begin{array}{l}0.006^{++} \\
(0.002)\end{array}$ & - & - & - & $\begin{array}{l}0.065^{+\dagger} \\
(0.002)\end{array}$ & $\begin{array}{l}0.055^{++} \\
(0.002)\end{array}$ & $\begin{array}{l}0.027^{++} \\
(0.005)\end{array}$ & _ & 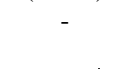 & - \\
\hline Overschooling & - & - & - & $\begin{array}{l}0.086^{++} \\
(0.012)\end{array}$ & $\begin{array}{l}0.047^{++} \\
(0.004)\end{array}$ & $\begin{array}{c}0.003 \\
(0.005)\end{array}$ & $\begin{array}{c}-0.049^{+\dagger} \\
(0.014)\end{array}$ & $\begin{array}{c}-0.017^{+\dagger} \\
(0.007)\end{array}$ & $\begin{array}{l}-0.005 \\
(0.007)\end{array}$ & $\begin{array}{l}0.055^{++} \\
(0.004)\end{array}$ & $\begin{array}{l}0.049^{++} \\
(0.002)\end{array}$ & $\begin{array}{l}0.023^{++} \\
(0.005)\end{array}$ & $\begin{array}{l}-0.001 \\
(0.010)\end{array}$ & $\begin{array}{l}-0.009^{+} \\
(0.005)\end{array}$ & $\begin{array}{c}-0.008 \\
(0.006)\end{array}$ \\
\hline Underschooling & - & - & - & $\begin{array}{c}-0.069^{++} \\
(0.013)\end{array}$ & $\begin{array}{c}-0.059^{++} \\
(0.007)\end{array}$ & $\begin{array}{l}-0.015^{+} \\
(0.008)\end{array}$ & $\begin{array}{l}0.050^{+\dagger} \\
(0.014)\end{array}$ & $\begin{array}{c}0.007 \\
(0.007)\end{array}$ & $\begin{array}{l}-0.004 \\
(0.007)\end{array}$ & $\begin{array}{c}-0.025^{++} \\
(0.004)\end{array}$ & $\begin{array}{c}-0.047^{++} \\
(0.002)\end{array}$ & $\begin{array}{c}-0.026^{++} \\
(0.005)\end{array}$ & $\begin{array}{l}0.106^{++} \\
(0.010)\end{array}$ & $\begin{array}{l}0.015^{++} \\
(0.005)\end{array}$ & $\begin{array}{l}-0.005 \\
(0.005)\end{array}$ \\
\hline Female & $\begin{array}{c}-0.157^{+\dagger} \\
(0.012)\end{array}$ & $\begin{array}{c}-0.192^{++} \\
(0.011)\end{array}$ & - & $\begin{array}{c}-0.161^{++} \\
(0.012)\end{array}$ & $\begin{array}{c}-0.206^{++} \\
(0.011)\end{array}$ & & $\begin{array}{c}-0.159^{++} \\
(0.012)\end{array}$ & $\begin{array}{c}-0.192^{++} \\
(0.011)\end{array}$ & (1) & $\begin{array}{c}-0.159^{+\dagger} \\
(0.012)\end{array}$ & $\begin{array}{c}-0.192^{++} \\
(0.011)\end{array}$ & $(0.000)$ & $\begin{array}{c}-0.166^{+\dagger} \\
(0.012)\end{array}$ & $\begin{array}{c}-0.193^{++} \\
(0.011)\end{array}$ & $10.000)$ \\
\hline Married & $\begin{array}{l}0.051^{++} \\
(0.010)\end{array}$ & $\begin{array}{l}0.037^{++} \\
(0.006)\end{array}$ & $\begin{array}{l}0.030^{+\dagger} \\
(0.006)\end{array}$ & $\begin{array}{c}-0.050^{++} \\
(0.010)\end{array}$ & $\begin{array}{c}-0.035 \\
(0.006)\end{array}$ & $\begin{array}{l}0.031^{++} \\
(0.006)\end{array}$ & $\begin{array}{l}0.050^{++} \\
(0.011)\end{array}$ & $\begin{array}{l}0.036^{++} \\
(0.006)\end{array}$ & $\begin{array}{l}0.030^{+\dagger} \\
(0.006)\end{array}$ & $\begin{array}{l}0.051^{++} \\
(0.010)\end{array}$ & $\begin{array}{l}0.037^{++} \\
(0.006)\end{array}$ & $\begin{array}{l}0.030^{++} \\
(0.006)\end{array}$ & $\begin{array}{l}0.052^{++} \\
(0.010)\end{array}$ & $\begin{array}{l}0.037^{++} \\
(0.006)\end{array}$ & $\begin{array}{l}0.030^{++} \\
(0.006)\end{array}$ \\
\hline Age & $\begin{array}{l}0.037^{++} \\
(0.004)\end{array}$ & $\begin{array}{l}0.039^{++} \\
(0.002)\end{array}$ & $\begin{array}{l}0.097^{++} \\
(0.002)\end{array}$ & $\begin{array}{l}0.035^{++} \\
(0.003)\end{array}$ & $\begin{array}{l}0.038^{++} \\
(0.002)\end{array}$ & $\begin{array}{l}0.097^{++} \\
(0.002)\end{array}$ & $\begin{array}{l}0.037^{++} \\
(0.004)\end{array}$ & $\begin{array}{l}0.039^{++} \\
(0.002)\end{array}$ & $\begin{array}{l}0.037^{++} \\
(0.002)\end{array}$ & $\begin{array}{l}0.035^{++} \\
(0.003)\end{array}$ & $\begin{array}{l}0.038^{++} \\
(0.002)\end{array}$ & $\begin{array}{l}0.097^{++} \\
(0.002)\end{array}$ & $\begin{array}{l}0.036^{++} \\
(0.004)\end{array}$ & $\begin{array}{l}0.038^{++} \\
(0.002)\end{array}$ & $\begin{array}{l}0.097^{++} \\
(0.002)\end{array}$ \\
\hline $\operatorname{Age}^{2} * 10^{-2}$ & $\begin{array}{c}-0.040^{++} \\
(0.004)\end{array}$ & $\begin{array}{c}-0.040^{++} \\
(0.002)\end{array}$ & $\begin{array}{c}-0.039^{++} \\
(0.002)\end{array}$ & $\begin{array}{c}-0.037^{++} \\
(0.004)\end{array}$ & $\begin{array}{c}-0.040^{++} \\
(0.002)\end{array}$ & $\begin{array}{c}-0.040^{++} \\
(0.002)\end{array}$ & $\begin{array}{c}-0.040^{++} \\
(0.004)\end{array}$ & $\begin{array}{c}-0.040^{++} \\
(0.002)\end{array}$ & $\begin{array}{c}-0.039^{+\dagger} \\
(0.002)\end{array}$ & $\begin{array}{c}-0.038^{+\dagger} \\
(0.004)\end{array}$ & $\begin{array}{c}-0.039^{++} \\
(0.002)\end{array}$ & $\begin{array}{c}-0.039^{++} \\
(0.002)\end{array}$ & $\begin{array}{c}-0.040^{+\dagger} \\
(0.004)\end{array}$ & $\begin{array}{c}-0.039^{++} \\
(0.002)\end{array}$ & $\begin{array}{c}-0.039^{++} \\
(0.002)\end{array}$ \\
\hline Tenure & $\begin{array}{l}0.005^{++} \\
(0.001)\end{array}$ & $\begin{array}{l}0.003^{+\dagger} \\
(0.001)\end{array}$ & $\begin{array}{c}0.001 \\
(0.001)\end{array}$ & $\begin{array}{l}0.005^{+\dagger} \\
(0.001)\end{array}$ & $\begin{array}{l}0.003^{+\dagger} \\
(0.001)\end{array}$ & $\begin{array}{c}0.001 \\
(0.001)\end{array}$ & $\begin{array}{l}0.005^{+\dagger} \\
(0.001)\end{array}$ & $\begin{array}{l}0.003^{+\dagger} \\
(0.001)\end{array}$ & $\begin{array}{c}0.001 \\
(0.001)\end{array}$ & $\begin{array}{l}0.006^{+\dagger} \\
(0.001)\end{array}$ & $\begin{array}{l}0.003^{++} \\
(0.001)\end{array}$ & $\begin{array}{c}0.001 \\
(0.001)\end{array}$ & $\begin{array}{l}0.005^{++} \\
(0.001)\end{array}$ & $\begin{array}{l}0.003^{+\dagger} \\
(0.001)\end{array}$ & $\begin{array}{c}0.001 \\
(0.001)\end{array}$ \\
\hline Tenure $^{2 * 10^{-2}}$ & $\begin{array}{c}0.000 \\
(0.004)\end{array}$ & $\begin{array}{c}0.000 \\
(0.002)\end{array}$ & $\begin{array}{l}-0.001 \\
(0.002)\end{array}$ & $\begin{array}{c}-0.002 \\
(0.004)\end{array}$ & $\begin{array}{c}0.001 \\
(0.002)\end{array}$ & $\begin{array}{l}-0.001 \\
(0.002)\end{array}$ & $\begin{array}{c}0.000 \\
(0.000)\end{array}$ & $\begin{array}{c}0.000 \\
(0.002)\end{array}$ & $\begin{array}{l}-0.001 \\
(0.002)\end{array}$ & $\begin{array}{c}-0.003 \\
(0.004)\end{array}$ & $\begin{array}{c}0.001 \\
(0.002)\end{array}$ & $\begin{array}{c}0.001 \\
(0.002)\end{array}$ & $\begin{array}{l}-0.002 \\
(0.004)\end{array}$ & $\begin{array}{c}0.000 \\
(0.002)\end{array}$ & $\begin{array}{l}-0.001 \\
(0.002)\end{array}$ \\
\hline Firm $<20$ & $\begin{array}{c}-0.199^{++} \\
(0.015)\end{array}$ & $\begin{array}{c}-0.105^{++} \\
(0.007)\end{array}$ & $\begin{array}{c}-0.067^{++} \\
(0.008)\end{array}$ & $\begin{array}{c}-0.184^{++} \\
(0.015)\end{array}$ & $\begin{array}{c}-0.108^{+t} \\
(0.007)\end{array}$ & $\begin{array}{c}-0.067^{++} \\
(0.008)\end{array}$ & $\begin{array}{c}-0.196^{++} \\
(0.015)\end{array}$ & $\begin{array}{c}-0.105^{++} \\
(0.007)\end{array}$ & $\begin{array}{c}-0.067^{+\dagger} \\
(0.008)\end{array}$ & $\begin{array}{c}-0.190^{++} \\
(0.015)\end{array}$ & $\begin{array}{c}-0.106^{++} \\
(0.007)\end{array}$ & $\begin{array}{c}-0.067^{++} \\
(0.008)\end{array}$ & $\begin{array}{c}-0.191^{++} \\
(0.015)\end{array}$ & $\begin{array}{c}-0.105^{++} \\
(0.007)\end{array}$ & $\begin{array}{c}-0.067^{++} \\
(0.008)\end{array}$ \\
\hline $19<$ Firm $<200$ & $\begin{array}{c}-0.095^{+\dagger} \\
(0.011)\end{array}$ & $\begin{array}{c}-0.042^{++} \\
(0.005)\end{array}$ & $\begin{array}{c}-0.022^{++} \\
(0.006)\end{array}$ & $\begin{array}{c}-0.096^{+\dagger} \\
(0.011)\end{array}$ & $\begin{array}{c}-0.045^{++} \\
(0.006)\end{array}$ & $\begin{array}{c}-0.021^{++} \\
(0.006)\end{array}$ & $\begin{array}{c}-0.096^{++} \\
(0.011)\end{array}$ & $\begin{array}{c}-0.042^{++} \\
(0.005)\end{array}$ & $\begin{array}{c}-0.022^{+\dagger} \\
(0.006)\end{array}$ & $\begin{array}{c}-0.093^{+\dagger} \\
(0.011)\end{array}$ & $\begin{array}{c}-0.043^{++} \\
(0.005)\end{array}$ & $\begin{array}{c}-0.022^{++} \\
(0.006)\end{array}$ & $\begin{array}{c}-0.090^{+\dagger} \\
(0.011)\end{array}$ & $\begin{array}{c}-0.042^{++} \\
(0.005)\end{array}$ & $\begin{array}{c}-0.022^{++} \\
(0.006)\end{array}$ \\
\hline $199<$ Firm<2000 & $\begin{array}{c}-0.045^{+\dagger} \\
(0.010)\end{array}$ & $\begin{array}{c}-0.011^{++} \\
(0.005)\end{array}$ & $\begin{array}{l}-0.001 \\
(0.005)\end{array}$ & $\begin{array}{c}-0.037^{++} \\
(0.010)\end{array}$ & $\begin{array}{c}-0.012^{++} \\
(0.005)\end{array}$ & $\begin{array}{c}0.000 \\
(0.005)\end{array}$ & $\begin{array}{c}-0.042^{++} \\
(0.010)\end{array}$ & $\begin{array}{c}-0.011^{++} \\
(0.005)\end{array}$ & $\begin{array}{c}-0.001^{+\dagger} \\
(0.005)\end{array}$ & $\begin{array}{c}-0.038^{+\dagger} \\
(0.010)\end{array}$ & $\begin{array}{c}-0.012^{++} \\
(0.005)\end{array}$ & $\begin{array}{l}0.000^{++} \\
(0.005)\end{array}$ & $\begin{array}{c}-0.039^{+\dagger} \\
(0.010)\end{array}$ & $\begin{array}{c}-0.011^{++} \\
(0.005)\end{array}$ & $\begin{array}{l}-0.001 \\
(0.005)\end{array}$ \\
\hline North & $\begin{array}{l}-0.023^{+} \\
(0.012)\end{array}$ & $\begin{array}{c}0.002 \\
(0.011)\end{array}$ & $\begin{array}{l}0.124^{++} \\
(0.024)\end{array}$ & $\begin{array}{c}-0.027^{++} \\
(0.012)\end{array}$ & $\begin{array}{l}-0.003 \\
(0.011)\end{array}$ & $\begin{array}{l}0.122^{++} \\
(0.002)\end{array}$ & $\begin{array}{l}-0.024^{+} \\
(0.012)\end{array}$ & $\begin{array}{c}0.001 \\
(0.011)\end{array}$ & $\begin{array}{l}0.124^{++} \\
(0.024)\end{array}$ & $\begin{array}{c}-0.025^{+\dagger} \\
(0.012)\end{array}$ & $\begin{array}{l}-0.001 \\
(0.011)\end{array}$ & $\begin{array}{l}0.122^{++} \\
(0.024)\end{array}$ & $\begin{array}{c}-0.024^{+\dagger} \\
(0.012)\end{array}$ & $\begin{array}{c}0.001 \\
(0.011)\end{array}$ & $\begin{array}{l}0.124^{++} \\
(0.024)\end{array}$ \\
\hline South & $\begin{array}{l}-0.003 \\
(0.011)\end{array}$ & $\begin{array}{c}0.016 \\
(0.010)\end{array}$ & $\begin{array}{l}0.097^{++} \\
(0.026)\end{array}$ & $\begin{array}{l}-0.003 \\
(0.010)\end{array}$ & $\begin{array}{c}0.012 \\
(0.010)\end{array}$ & $\begin{array}{l}0.098^{++} \\
(0.026)\end{array}$ & $\begin{array}{l}-0.003 \\
(0.011)\end{array}$ & $\begin{array}{c}0.016 \\
(0.010)\end{array}$ & $\begin{array}{l}0.097^{++} \\
(0.026)\end{array}$ & $\begin{array}{c}0.002 \\
(0.010)\end{array}$ & $\begin{array}{c}0.015 \\
(0.010)\end{array}$ & $\begin{array}{l}0.097^{++} \\
(0.026)\end{array}$ & $\begin{array}{l}-0.003 \\
(0.010)\end{array}$ & $\begin{array}{l}0.015 \\
(0.010)\end{array}$ & $\begin{array}{l}0.098^{++} \\
(0.026)\end{array}$ \\
\hline Agriculture/Mining & $\begin{array}{c}0.010 \\
(0.025)\end{array}$ & $\begin{array}{c}0.014 \\
(0.014)\end{array}$ & $\begin{array}{c}0.010 \\
(0.016)\end{array}$ & $\begin{array}{c}0.005 \\
(0.023)\end{array}$ & $\begin{array}{c}0.008 \\
(0.014)\end{array}$ & $\begin{array}{c}0.008 \\
(0.016)\end{array}$ & $\begin{array}{c}0.010 \\
(0.024)\end{array}$ & $\begin{array}{c}0.015 \\
(0.014)\end{array}$ & $\begin{array}{c}0.010 \\
(0.016)\end{array}$ & $\begin{array}{c}0.006 \\
(0.023)\end{array}$ & $\begin{array}{c}0.014 \\
(0.014)\end{array}$ & $\begin{array}{c}0.009 \\
(0.016)\end{array}$ & $\begin{array}{c}0.001 \\
(0.024)\end{array}$ & $\begin{array}{c}0.013 \\
(0.014)\end{array}$ & $\begin{array}{c}0.009 \\
(0.016)\end{array}$ \\
\hline Production & $\begin{array}{l}0.036^{++} \\
(0.013)\end{array}$ & $\begin{array}{c}0.005 \\
(0.006)\end{array}$ & $\begin{array}{l}-0.003 \\
(0.006)\end{array}$ & $\begin{array}{c}-0.032^{++} \\
(0.012)\end{array}$ & $\begin{array}{c}0.004 \\
(0.006)\end{array}$ & $\begin{array}{l}-0.003 \\
(0.006)\end{array}$ & $\begin{array}{l}0.035^{+\dagger} \\
(0.013)\end{array}$ & $\begin{array}{c}0.005 \\
(0.006)\end{array}$ & $\begin{array}{l}-0.003 \\
(0.006)\end{array}$ & $\begin{array}{l}0.030^{++} \\
(0.012)\end{array}$ & $\begin{array}{c}0.005 \\
(0.006)\end{array}$ & $\begin{array}{l}-0.003 \\
(0.006)\end{array}$ & $\begin{array}{l}0.034^{++} \\
(0.012)\end{array}$ & $\begin{array}{c}0.005 \\
(0.006)\end{array}$ & $\begin{array}{l}-0.003 \\
(0.006)\end{array}$ \\
\hline Trade & $\begin{array}{c}-0.106^{++} \\
(0.016)\end{array}$ & $\begin{array}{c}-0.051^{++} \\
(0.008)\end{array}$ & $\begin{array}{c}-0.040^{++} \\
(0.008)\end{array}$ & $\begin{array}{c}-0.103^{++} \\
(0.015)\end{array}$ & $\begin{array}{c}-0.051^{++} \\
(0.008)\end{array}$ & $\begin{array}{c}-0.040^{++} \\
(0.008)\end{array}$ & $\begin{array}{c}-0.105^{++} \\
(0.016)\end{array}$ & $\begin{array}{c}-0.051^{++} \\
(0.008)\end{array}$ & $\begin{array}{c}-0.040^{++} \\
(0.008)\end{array}$ & $\begin{array}{c}-0.100^{++} \\
(0.015)\end{array}$ & $\begin{array}{c}-0.050^{++} \\
(0.008)\end{array}$ & $\begin{array}{c}-0.040^{++} \\
(0.008)\end{array}$ & $\begin{array}{c}-0.101^{++} \\
(0.015)\end{array}$ & $\begin{array}{c}-0.050^{++} \\
(0.008)\end{array}$ & $\begin{array}{c}-0.040^{++} \\
(0.008)\end{array}$ \\
\hline Services & $\begin{array}{c}0.001 \\
(0.016)\end{array}$ & $\begin{array}{l}-0.011 \\
(0.008)\end{array}$ & $\begin{array}{c}-0.022^{++} \\
(0.009)\end{array}$ & $\begin{array}{c}-0.039^{++} \\
(0.015)\end{array}$ & $\begin{array}{l}-0.005 \\
(0.008)\end{array}$ & $\begin{array}{c}-0.023^{++} \\
(0.009)\end{array}$ & $\begin{array}{l}-0.009 \\
(0.015)\end{array}$ & $\begin{array}{l}-0.012 \\
(0.008)\end{array}$ & $\begin{array}{l}-0.022 \\
(0.009)\end{array}$ & $\begin{array}{l}-0.016 \\
(0.015)\end{array}$ & $\begin{array}{l}-0.012 \\
(0.008)\end{array}$ & $\begin{array}{l}-0.022^{++} \\
(0.009)\end{array}$ & $\begin{array}{l}-0.012 \\
(0.015)\end{array}$ & $\begin{array}{l}-0.011 \\
(0.008)\end{array}$ & $\begin{array}{c}-0.022^{++} \\
(0.009)\end{array}$ \\
\hline $\begin{array}{l}\text { Privat Households / } \\
\text { Government }\end{array}$ & $\begin{array}{l}-0.055^{++} \\
(0.015)\end{array}$ & $\begin{array}{l}-0.033^{++} \\
(0.009)\end{array}$ & $\begin{array}{c}-0.036^{++} \\
(0.010)\end{array}$ & $\begin{array}{c}-0.083^{++} \\
(0.014)\end{array}$ & $\begin{array}{c}-0.036^{++} \\
(0.009)\end{array}$ & $\begin{array}{c}-0.037^{++} \\
(0.010)\end{array}$ & $\begin{array}{c}-0.057^{++} \\
(0.015)\end{array}$ & $\begin{array}{c}-0.033^{++} \\
(0.009)\end{array}$ & $\begin{array}{c}-0.036^{++} \\
(0.010)\end{array}$ & $\begin{array}{c}-0.056^{++} \\
(0.014)\end{array}$ & $\begin{array}{c}-0.033^{++} \\
(0.009)\end{array}$ & $\begin{array}{l}-0.036^{++} \\
(0.010)\end{array}$ & $\begin{array}{c}-0.062^{++} \\
(0.014)\end{array}$ & $\begin{array}{c}-0.034^{++} \\
(0.009)\end{array}$ & $\begin{array}{c}-0.036^{++} \\
(0.010)\end{array}$ \\
\hline Constant & $\begin{array}{l}1.317^{++} \\
(0.072)\end{array}$ & $\begin{array}{l}1.300^{++} \\
(0.043)\end{array}$ & $\begin{array}{c}-0.563^{++} \\
(0.068)\end{array}$ & $\begin{array}{l}1.138^{++} \\
(0.073)\end{array}$ & $\begin{array}{l}1.409^{++} \\
(0.042)\end{array}$ & $\begin{array}{l}0.347^{++} \\
(0.050)\end{array}$ & $\begin{array}{l}1.274^{++} \\
(0.073)\end{array}$ & $\begin{array}{l}1.290^{++} \\
(0.043)\end{array}$ & $\begin{array}{c}-0.562^{+\dagger} \\
(0.068)\end{array}$ & $\begin{array}{l}1.266^{++} \\
(0.071)\end{array}$ & $\begin{array}{l}1.283^{++} \\
(0.042)\end{array}$ & $\begin{array}{c}-0.571^{++} \\
(0.068)\end{array}$ & $\begin{array}{l}1.240^{++} \\
(0.071)\end{array}$ & $\begin{array}{l}1.292^{++} \\
(0.043)\end{array}$ & $\begin{array}{c}-0.561^{++} \\
(0.068)\end{array}$ \\
\hline $\mathrm{R}^{2}$ & 0.620 & 0.606 & 0.079 & 0.636 & 0.602 & 0.064 & 0.622 & 0.607 & 0.079 & 0.637 & 0.613 & 0.080 & 0.629 & 0.609 & 0.079 \\
\hline
\end{tabular}


Appendix Table 2 (NOT intended for publication): Estimation Results based on Male Sample

\begin{tabular}{|c|c|c|c|c|c|c|c|c|c|c|c|c|c|c|c|}
\hline & \multirow{2}{*}{\multicolumn{3}{|c|}{ Human Capital }} & \multicolumn{6}{|c|}{ Mean-Index } & \multicolumn{6}{|c|}{ Mode-Index } \\
\hline & & & & \multicolumn{3}{|c|}{ Duncan and Hoffman } & \multicolumn{3}{|c|}{ Verdugo and Verdugo } & \multicolumn{3}{|c|}{ Duncan and Hoffman } & \multicolumn{3}{|c|}{ Verdugo and Verdugo } \\
\hline & Pooled & $\begin{array}{c}\text { Random } \\
\text { Effects }\end{array}$ & $\begin{array}{c}\text { Fixed } \\
\text { Effects }\end{array}$ & Pooled & $\begin{array}{c}\text { Random } \\
\text { Effects }\end{array}$ & $\begin{array}{c}\text { Fixed } \\
\text { Effects }\end{array}$ & Pooled & $\begin{array}{c}\text { Random } \\
\text { Effects }\end{array}$ & $\begin{array}{l}\text { Fixed } \\
\text { Effects }\end{array}$ & Pooled & $\begin{array}{c}\text { Random } \\
\text { Effects }\end{array}$ & $\begin{array}{c}\text { Fixed } \\
\text { Effects }\end{array}$ & Pooled & $\begin{array}{c}\text { Random } \\
\text { Effects }\end{array}$ & $\begin{array}{c}\text { Fixed } \\
\text { Effects }\end{array}$ \\
\hline Years of Schooling & $\begin{array}{l}0.060^{+\dagger} \\
(0.002)\end{array}$ & $\begin{array}{l}0.053^{++} \\
(0.002)\end{array}$ & $\begin{array}{l}0.025^{++} \\
(0.005)\end{array}$ & - & - & 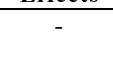 & $\begin{array}{l}0.065^{+\dagger} \\
(0.003)\end{array}$ & $\begin{array}{l}0.054^{++} \\
(0.002)\end{array}$ & $\begin{array}{l}0.024^{++} \\
(0.005)\end{array}$ & - & - & 年 & $\begin{array}{l}0.066^{++} \\
(0.003)\end{array}$ & $\begin{array}{l}0.054^{++} \\
(0.002)\end{array}$ & $\begin{array}{l}0.024^{++} \\
(0.005)\end{array}$ \\
\hline Required Schooling & - & - & - & $\begin{array}{l}0.079^{++} \\
(0.003)\end{array}$ & $\begin{array}{l}0.045^{++} \\
(0.002)\end{array}$ & $\begin{array}{l}0.008^{++} \\
(0.003)\end{array}$ & - & - & - & $\begin{array}{l}0.066^{++} \\
(0.003)\end{array}$ & $\begin{array}{l}0.055^{++} \\
(0.002)\end{array}$ & $\begin{array}{l}0.026^{++} \\
(0.005)\end{array}$ & - & - & - \\
\hline Overschooling & - & - & - & $\begin{array}{l}0.105^{++} \\
(0.009)\end{array}$ & $\begin{array}{c}-0.062^{++} \\
(0.008)\end{array}$ & $\begin{array}{c}0.003 \\
(0.006)\end{array}$ & $\begin{array}{l}-0.026 \\
(0.016)\end{array}$ & $\begin{array}{l}-0.011 \\
(0.007)\end{array}$ & $\begin{array}{l}-0.005 \\
(0.008)\end{array}$ & $\begin{array}{l}0.062^{++} \\
(0.004)\end{array}$ & $\begin{array}{l}0.050^{++} \\
(0.002)\end{array}$ & $\begin{array}{l}0.023^{++} \\
(0.006)\end{array}$ & $\begin{array}{l}-0.010 \\
(0.011)\end{array}$ & $\begin{array}{c}-0.004 \\
(0.006)\end{array}$ & $\begin{array}{l}-0.005 \\
(0.006)\end{array}$ \\
\hline Underschooling & - & - & - & $\begin{array}{c}-0.056^{++} \\
(0.015)\end{array}$ & $\begin{array}{l}0.052^{++} \\
(0.007)\end{array}$ & $\begin{array}{c}-0.021^{++} \\
(0.010)\end{array}$ & $\begin{array}{l}0.072^{++} \\
(0.016)\end{array}$ & $\begin{array}{c}0.011 \\
(0.008)\end{array}$ & $\begin{array}{l}-0.005 \\
(0.008)\end{array}$ & $\begin{array}{c}-0.023^{++} \\
(0.004)\end{array}$ & $\begin{array}{c}-0.047^{++} \\
(0.002)\end{array}$ & $\begin{array}{c}-0.025^{++} \\
(0.006)\end{array}$ & $\begin{array}{l}0.118^{++} \\
(0.012)\end{array}$ & $\begin{array}{l}0.022^{++} \\
(0.006)\end{array}$ & $\begin{array}{l}-0.001 \\
(0.006)\end{array}$ \\
\hline Married & $\begin{array}{l}0.082^{++} \\
(0.012)\end{array}$ & $\begin{array}{l}0.052^{+\dagger} \\
(0.007)\end{array}$ & $\begin{array}{l}0.038^{+\dagger} \\
(0.007)\end{array}$ & $\begin{array}{l}0.082^{++} \\
(0.012)\end{array}$ & $\begin{array}{l}0.040^{++} \\
(0.002)\end{array}$ & $\begin{array}{l}0.038^{++} \\
(0.007)\end{array}$ & $\begin{array}{l}0.081^{++} \\
(0.012)\end{array}$ & $\begin{array}{l}0.052^{++} \\
(0.007)\end{array}$ & $\begin{array}{l}0.038^{++} \\
(0.007)\end{array}$ & $\begin{array}{l}0.082^{++} \\
(0.012)\end{array}$ & $\begin{array}{l}0.053^{++} \\
(0.007)\end{array}$ & $\begin{array}{l}0.037^{++} \\
(0.007)\end{array}$ & $\begin{array}{l}0.081^{++} \\
(0.012)\end{array}$ & $\begin{array}{l}0.052^{++} \\
(0.007)\end{array}$ & $\begin{array}{l}0.038^{++} \\
(0.007)\end{array}$ \\
\hline Age & $\begin{array}{l}0.037^{++} \\
(0.004)\end{array}$ & $\begin{array}{l}0.040^{++} \\
(0.002)\end{array}$ & $\begin{array}{l}0.097^{++} \\
(0.002)\end{array}$ & $\begin{array}{l}0.035^{++} \\
(0.004)\end{array}$ & $\begin{array}{c}-0.041^{++} \\
(0.002)\end{array}$ & $\begin{array}{l}0.097^{++} \\
(0.002)\end{array}$ & $\begin{array}{l}0.038^{++} \\
(0.004)\end{array}$ & $\begin{array}{l}0.040^{++} \\
(0.002)\end{array}$ & $\begin{array}{l}0.097^{++} \\
(0.002)\end{array}$ & $\begin{array}{l}0.035^{++} \\
(0.004)\end{array}$ & $\begin{array}{l}0.040^{++} \\
(0.002)\end{array}$ & $\begin{array}{l}0.097^{+\dagger} \\
(0.002)\end{array}$ & $\begin{array}{l}0.037^{++} \\
(0.004)\end{array}$ & $\begin{array}{l}0.040^{++} \\
(0.002)\end{array}$ & $\begin{array}{l}0.097^{++} \\
(0.002)\end{array}$ \\
\hline $\operatorname{Age}^{2 *} 10^{-2}$ & $\begin{array}{c}-0.040^{++} \\
(0.005)\end{array}$ & $\begin{array}{c}-0.041^{++} \\
(0.002)\end{array}$ & $\begin{array}{c}-0.040^{++} \\
(0.003)\end{array}$ & $\begin{array}{c}-0.037^{++} \\
(0.004)\end{array}$ & $\begin{array}{l}0.002^{++} \\
(0.001)\end{array}$ & $\begin{array}{l}0.041^{++} \\
(0.003)\end{array}$ & $\begin{array}{l}0.040^{++} \\
(0.005)\end{array}$ & $\begin{array}{c}-0.041^{++} \\
(0.002)\end{array}$ & $\begin{array}{c}-0.040^{++} \\
(0.003)\end{array}$ & $\begin{array}{c}-0.037^{++} \\
(0.004)\end{array}$ & $\begin{array}{c}-0.040^{++} \\
(0.002)\end{array}$ & $\begin{array}{c}-0.040^{++} \\
(0.003)\end{array}$ & $\begin{array}{c}-0.040^{++} \\
(0.005)\end{array}$ & $\begin{array}{c}-0.040^{++} \\
(0.002)\end{array}$ & $\begin{array}{c}-0.040^{++} \\
(0.003)\end{array}$ \\
\hline Tenure & $\begin{array}{l}0.003^{+} \\
(0.002)\end{array}$ & $\begin{array}{l}0.002^{++} \\
(0.001)\end{array}$ & $\begin{array}{c}0.005 \\
(0.001)\end{array}$ & $\begin{array}{l}0.003^{++} \\
(0.001)\end{array}$ & $\begin{array}{c}0.002 \\
(0.002)\end{array}$ & $\begin{array}{c}0.001 \\
(0.001)\end{array}$ & $\begin{array}{l}0.003^{+} \\
(0.002)\end{array}$ & $\begin{array}{l}0.002^{++} \\
(0.001)\end{array}$ & $\begin{array}{c}0.001 \\
(0.001)\end{array}$ & $\begin{array}{l}0.004^{++} \\
(0.002)\end{array}$ & $\begin{array}{l}0.002^{++} \\
(0.076)\end{array}$ & $\begin{array}{c}0.001 \\
(0.001)\end{array}$ & $\begin{array}{l}0.004^{++} \\
(0.002)\end{array}$ & $\begin{array}{l}0.002^{++} \\
(0.001)\end{array}$ & $\begin{array}{c}0.001 \\
(0.008)\end{array}$ \\
\hline Tenure $^{2} * 10^{-2}$ & $\begin{array}{c}0.003 \\
(0.004)\end{array}$ & $\begin{array}{c}0.003 \\
(0.002)\end{array}$ & $\begin{array}{c}0.001 \\
(0.003)\end{array}$ & $\begin{array}{c}0.001 \\
(0.004)\end{array}$ & $\begin{array}{c}-0.104^{++} \\
(0.008)\end{array}$ & $\begin{array}{c}0.001 \\
(0.003)\end{array}$ & $\begin{array}{c}0.003 \\
(0.004)\end{array}$ & $\begin{array}{c}0.003 \\
(0.002)\end{array}$ & $\begin{array}{c}0.001 \\
(0.003)\end{array}$ & $\begin{array}{c}0.000 \\
(0.004)\end{array}$ & $\begin{array}{l}0.003^{++} \\
(0.002)\end{array}$ & $\begin{array}{c}0.001 \\
(0.003)\end{array}$ & $\begin{array}{c}0.001 \\
(0.004)\end{array}$ & $\begin{array}{c}0.003 \\
(0.002)\end{array}$ & $\begin{array}{c}0.001 \\
(0.003)\end{array}$ \\
\hline Firm $<20$ & $\begin{array}{c}-0.185^{++} \\
(0.017)\end{array}$ & $\begin{array}{c}-0.101^{++} \\
(0.008)\end{array}$ & $\begin{array}{c}-0.068^{+\dagger} \\
(0.009)\end{array}$ & $\begin{array}{c}-0.170^{++} \\
(0.017)\end{array}$ & $\begin{array}{c}-0.105^{++} \\
(0.008)\end{array}$ & $\begin{array}{c}-0.067^{++} \\
(0.009)\end{array}$ & $\begin{array}{c}-0.180^{++} \\
(0.017)\end{array}$ & $\begin{array}{c}-0.101^{++} \\
(0.008)\end{array}$ & $\begin{array}{c}-0.068^{++} \\
(0.009)\end{array}$ & $\begin{array}{c}-0.174^{++} \\
(0.017)\end{array}$ & $\begin{array}{c}-0.102^{++} \\
(0.008)\end{array}$ & $\begin{array}{c}-0.068^{++} \\
(0.009)\end{array}$ & $\begin{array}{c}-0.174^{++} \\
(0.017)\end{array}$ & $\begin{array}{c}-0.101^{++} \\
(0.008)\end{array}$ & $\begin{array}{c}-0.068^{++} \\
(0.009)\end{array}$ \\
\hline $19<$ Firm $<200$ & $\begin{array}{c}-0.092^{++} \\
(0.012)\end{array}$ & $\begin{array}{c}-0.035^{++} \\
(0.006)\end{array}$ & $\begin{array}{c}-0.015^{++} \\
(0.007)\end{array}$ & $\begin{array}{c}-0.093^{++} \\
(0.012)\end{array}$ & $\begin{array}{c}-0.039^{++} \\
(0.006)\end{array}$ & $\begin{array}{c}-0.014^{++} \\
(0.007)\end{array}$ & $\begin{array}{c}-0.092^{++} \\
(0.012)\end{array}$ & $\begin{array}{c}-0.035^{++} \\
(0.006)\end{array}$ & $\begin{array}{c}-0.015^{++} \\
(0.007)\end{array}$ & $\begin{array}{c}-0.087^{++} \\
(0.012)\end{array}$ & $\begin{array}{c}-0.037^{++} \\
(0.006)\end{array}$ & $\begin{array}{c}-0.015^{++} \\
(0.007)\end{array}$ & $\begin{array}{c}-0.087^{++} \\
(0.012)\end{array}$ & $\begin{array}{c}-0.036^{++} \\
(0.006)\end{array}$ & $\begin{array}{c}-0.015^{++} \\
(0.007)\end{array}$ \\
\hline 199<Firm<2000 & $\begin{array}{c}-0.034^{+\dagger} \\
(0.012)\end{array}$ & $\begin{array}{c}-0.008 \\
(0.006)\end{array}$ & $\begin{array}{c}0.002 \\
(0.006)\end{array}$ & $\begin{array}{c}-0.028^{++} \\
(0.011)\end{array}$ & $\begin{array}{c}-0.010^{\dagger} \\
(0.006)\end{array}$ & $\begin{array}{c}0.002 \\
(0.006)\end{array}$ & $\begin{array}{c}0.031 \\
(0.012)\end{array}$ & $\begin{array}{c}-0.008 \\
(0.006)\end{array}$ & $\begin{array}{c}0.002 \\
(0.006)\end{array}$ & $\begin{array}{c}-0.029^{+\dagger} \\
(0.011)\end{array}$ & $\begin{array}{c}-0.009 \\
(0.006)\end{array}$ & $\begin{array}{c}0.002 \\
(0.006)\end{array}$ & $\begin{array}{c}-0.028^{++} \\
(0.011)\end{array}$ & $\begin{array}{l}-0.008 \\
(0.006)\end{array}$ & $\begin{array}{c}0.002 \\
(0.006)\end{array}$ \\
\hline North & $\begin{array}{l}-0.024^{+} \\
(0.014)\end{array}$ & $\begin{array}{c}0.002 \\
(0.013)\end{array}$ & $\begin{array}{l}0.165^{++} \\
(0.028)\end{array}$ & $\begin{array}{c}-0.028^{++} \\
(0.014)\end{array}$ & $\begin{array}{l}-0.002 \\
(0.012)\end{array}$ & $\begin{array}{l}0.162^{++} \\
(0.028)\end{array}$ & $\begin{array}{l}-0.024^{+} \\
(0.014)\end{array}$ & $\begin{array}{c}0.002 \\
(0.013)\end{array}$ & $\begin{array}{l}0.165^{++} \\
(0.028)\end{array}$ & $\begin{array}{c}-0.026^{+} \\
(0.013)\end{array}$ & $\begin{array}{c}-0.002 \\
(0.012)\end{array}$ & $\begin{array}{l}0.161^{++} \\
(0.028)\end{array}$ & $\begin{array}{l}-0.023^{+} \\
(0.014)\end{array}$ & $\begin{array}{c}0.001 \\
(0.012)\end{array}$ & $\begin{array}{l}0.164^{++} \\
(0.028)\end{array}$ \\
\hline South & $\begin{array}{l}-0.005 \\
(0.012)\end{array}$ & $\begin{array}{c}0.013 \\
(0.011)\end{array}$ & $\begin{array}{l}0.105^{++} \\
(0.030)\end{array}$ & $\begin{array}{l}-0.004 \\
(0.011)\end{array}$ & $\begin{array}{c}0.012 \\
(0.011)\end{array}$ & $\begin{array}{l}0.107^{++} \\
(0.030)\end{array}$ & $\begin{array}{l}-0.006 \\
(0.012)\end{array}$ & $\begin{array}{c}0.013 \\
(0.011)\end{array}$ & $\begin{array}{l}0.105^{++} \\
(0.030)\end{array}$ & $\begin{array}{l}-0.004 \\
(0.011)\end{array}$ & $\begin{array}{c}0.012 \\
(0.011)\end{array}$ & $\begin{array}{l}0.105^{++} \\
(0.030)\end{array}$ & $\begin{array}{l}-0.004 \\
(0.012)\end{array}$ & $\begin{array}{c}0.012 \\
(0.011)\end{array}$ & $\begin{array}{l}0.105^{++} \\
(0.030)\end{array}$ \\
\hline Agriculture/Mining & $\begin{array}{c}0.004 \\
(0.026)\end{array}$ & $\begin{array}{c}0.013 \\
(0.015)\end{array}$ & $\begin{array}{c}0.010 \\
(0.016)\end{array}$ & $\begin{array}{c}0.003 \\
(0.025)\end{array}$ & $\begin{array}{c}0.007 \\
(0.015)\end{array}$ & $\begin{array}{c}0.008 \\
(0.016)\end{array}$ & $\begin{array}{c}0.003 \\
(0.026)\end{array}$ & $\begin{array}{c}0.014 \\
(0.015)\end{array}$ & $\begin{array}{c}0.010 \\
(0.016)\end{array}$ & $\begin{array}{l}-0.003 \\
(0.024)\end{array}$ & $\begin{array}{c}0.012 \\
(0.015)\end{array}$ & $\begin{array}{c}0.009 \\
(0.016)\end{array}$ & $\begin{array}{l}-0.011 \\
(0.026)\end{array}$ & $\begin{array}{c}0.011 \\
(0.015)\end{array}$ & $\begin{array}{c}0.010 \\
(0.016)\end{array}$ \\
\hline Production & $\begin{array}{l}0.040^{++} \\
(0.013)\end{array}$ & $\begin{array}{c}0.002 \\
(0.006)\end{array}$ & $\begin{array}{c}-0.012^{++} \\
(0.007)\end{array}$ & $\begin{array}{l}0.033^{++} \\
(0.013)\end{array}$ & $\begin{array}{c}0.001 \\
(0.006)\end{array}$ & $\begin{array}{l}-0.011^{+} \\
(0.007)\end{array}$ & $\begin{array}{l}0.039^{++} \\
(0.013)\end{array}$ & $\begin{array}{c}0.002 \\
(0.006)\end{array}$ & $\begin{array}{l}-0.011^{+} \\
(0.007)\end{array}$ & $\begin{array}{l}0.032^{++} \\
(0.013)\end{array}$ & $\begin{array}{c}0.002 \\
(0.006)\end{array}$ & $\begin{array}{l}-0.012^{+} \\
(0.007)\end{array}$ & $\begin{array}{l}0.037^{++} \\
(0.013)\end{array}$ & $\begin{array}{c}0.002 \\
(0.006)\end{array}$ & $\begin{array}{l}-0.012^{+} \\
(0.007)\end{array}$ \\
\hline Trade & $\begin{array}{c}-0.111^{++} \\
(0.017)\end{array}$ & $\begin{array}{c}-0.057^{++} \\
(0.008)\end{array}$ & $\begin{array}{c}-0.048^{+\dagger} \\
(0.009)\end{array}$ & $\begin{array}{c}-0.107^{++} \\
(0.017)\end{array}$ & $\begin{array}{c}-0.056^{++} \\
(0.008)\end{array}$ & $\begin{array}{c}-0.047^{++} \\
(0.099)\end{array}$ & $\begin{array}{c}-0.109^{++} \\
(0.017)\end{array}$ & $\begin{array}{c}-0.057^{++} \\
(0.008)\end{array}$ & $\begin{array}{c}-0.048^{++} \\
(0.009)\end{array}$ & $\begin{array}{c}-0.105^{++} \\
(0.017)\end{array}$ & $\begin{array}{c}-0.056^{++} \\
(0.008)\end{array}$ & $\begin{array}{c}-0.047^{++} \\
(0.009)\end{array}$ & $\begin{array}{c}-0.106^{++} \\
(0.017)\end{array}$ & $\begin{array}{c}-0.057^{++} \\
(0.008)\end{array}$ & $\begin{array}{c}-0.048^{++} \\
(0.009)\end{array}$ \\
\hline Services & $\begin{array}{l}-0.032^{+} \\
(0.019)\end{array}$ & $\begin{array}{c}-0.026^{+\dagger} \\
(0.010)\end{array}$ & $\begin{array}{c}-0.026^{++} \\
(0.011)\end{array}$ & $\begin{array}{c}-0.076^{++} \\
(0.019)\end{array}$ & $\begin{array}{c}-0.019^{+\dagger} \\
(0.010)\end{array}$ & $\begin{array}{c}-0.026^{++} \\
(0.011)\end{array}$ & $\begin{array}{c}-0.042^{++} \\
(0.019)\end{array}$ & $\begin{array}{c}-0.028^{++} \\
(0.010)\end{array}$ & $\begin{array}{c}-0.026^{++} \\
(0.011)\end{array}$ & $\begin{array}{c}-0.050^{+\dagger} \\
(0.018)\end{array}$ & $\begin{array}{c}-0.029^{+\dagger} \\
(0.009)\end{array}$ & $\begin{array}{c}-0.026^{++} \\
(0.011)\end{array}$ & $\begin{array}{c}-0.046^{++} \\
(0.019)\end{array}$ & $\begin{array}{c}-0.028^{+\dagger} \\
(0.010)\end{array}$ & $\begin{array}{c}-0.026^{++} \\
(0.011)\end{array}$ \\
\hline Privat Households / & $-0.069^{++}$ & $-0.049^{+\dagger}$ & $-0.043^{t+}$ & $-0.099^{++}$ & $-0.050^{++}$ & $-0.044^{++}$ & $-0.069^{++}$ & $-0.050^{++}$ & $-0.043^{++}$ & $-0.070^{++}$ & $-0.050^{++}$ & $-0.043^{++}$ & $-0.078^{++}$ & $-0.051^{++}$ & $-0.043^{++}$ \\
\hline Government & & & & & & & & & & & & & & & $(0.012)$ \\
\hline Constant & $\begin{array}{l}1.268^{+\dagger} \\
(0.084)\end{array}$ & $\begin{array}{c}-1.245^{+\dagger} \\
(0.048)\end{array}$ & $\begin{array}{c}-0.547^{++} \\
(0.077)\end{array}$ & $\begin{array}{l}1.107^{+\dagger} \\
(0.084)\end{array}$ & $\begin{array}{l}1.346^{++} \\
(0.048)\end{array}$ & $\begin{array}{c}-0.360^{++} \\
(0.057)\end{array}$ & $\begin{array}{l}1.214^{+\dagger} \\
(0.084)\end{array}$ & $\begin{array}{l}1.235^{+\dagger} \\
(0.049)\end{array}$ & $\begin{array}{c}-0.545^{++} \\
(0.078)\end{array}$ & $\begin{array}{l}1.238^{+\dagger} \\
(0.081)\end{array}$ & $\begin{array}{l}1.228^{+\dagger} \\
(0.048)\end{array}$ & $\begin{array}{c}-0.559^{\dagger+} \\
(0.077)\end{array}$ & $\begin{array}{l}1.189^{+\dagger} \\
(0.082)\end{array}$ & $\begin{array}{l}1.233^{+\dagger} \\
(0.048)\end{array}$ & $\begin{array}{c}-0.548^{++} \\
(0.077)\end{array}$ \\
\hline $\mathrm{R}^{2}$ & 0.619 & 0.604 & 0.081 & 0.635 & 0.599 & 0.066 & 0.621 & 0.605 & 0.081 & 0.639 & 0.613 & 0.083 & 0.630 & 0.609 & 0.081 \\
\hline
\end{tabular}


Appendix Table 3 (NOT intended for publication): Estimation Results based on Female Sample

\begin{tabular}{|c|c|c|c|c|c|c|c|c|c|c|c|c|c|c|c|}
\hline & \multirow{2}{*}{\multicolumn{3}{|c|}{ Human Capital }} & \multicolumn{6}{|c|}{ Mean-Index } & \multicolumn{6}{|c|}{ Mode-Index } \\
\hline & & & & \multicolumn{3}{|c|}{ Duncan and Hoffman } & \multicolumn{3}{|c|}{ Verdugo and Verdugo } & \multicolumn{3}{|c|}{ Duncan and Hoffman } & \multicolumn{3}{|c|}{ Verdugo and Verdugo } \\
\hline & Pooled & $\begin{array}{c}\text { Random } \\
\text { Effects }\end{array}$ & $\begin{array}{c}\text { Fixed } \\
\text { Effects }\end{array}$ & Pooled & $\begin{array}{c}\text { Random } \\
\text { Effects }\end{array}$ & $\begin{array}{c}\text { Fixed } \\
\text { Effects }\end{array}$ & Pooled & $\begin{array}{c}\text { Random } \\
\text { Effects }\end{array}$ & $\begin{array}{c}\text { Fixed } \\
\text { Effects }\end{array}$ & Pooled & $\begin{array}{c}\text { Random } \\
\text { Effects }\end{array}$ & $\begin{array}{l}\text { Fixed } \\
\text { Effects }\end{array}$ & Pooled & $\begin{array}{c}\text { Random } \\
\text { Effects }\end{array}$ & $\begin{array}{c}\text { Fixed } \\
\text { Effects }\end{array}$ \\
\hline Years of Schooling & $\begin{array}{l}0.051^{+\dagger} \\
(0.004)\end{array}$ & $\begin{array}{l}0.052^{++} \\
(0.004)\end{array}$ & $\begin{array}{l}0.030^{+\dagger} \\
(0.010)\end{array}$ & - & - & - & $\begin{array}{l}0.060^{+\dagger} \\
(0.004)\end{array}$ & $\begin{array}{l}0.055^{+t} \\
(0.004)\end{array}$ & $\begin{array}{l}0.031^{++} \\
(0.010)\end{array}$ & - & - & - & $\begin{array}{l}0.059^{++} \\
(0.004)\end{array}$ & $\begin{array}{l}0.053^{+\dagger} \\
(0.004)\end{array}$ & $\begin{array}{l}0.028^{+t} \\
(0.010)\end{array}$ \\
\hline Required Schooling & - & - & - & $\begin{array}{l}0.083^{++} \\
(0.005)\end{array}$ & $\begin{array}{l}0.047^{++} \\
(0.004)\end{array}$ & $\begin{array}{l}-0.001 \\
(0.005)\end{array}$ & - & - & 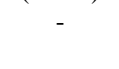 & $\begin{array}{l}0.063^{++} \\
(0.004)\end{array}$ & $\begin{array}{l}0.054^{+\dagger} \\
(0.004)\end{array}$ & $\begin{array}{l}0.028^{++} \\
(0.010)\end{array}$ & . & - & , \\
\hline Overschooling & - & - & - & $\begin{array}{c}0.007 \\
(0.037)\end{array}$ & $\begin{array}{c}0.041 \\
(0.011)\end{array}$ & $\begin{array}{c}0.008 \\
(0.013)\end{array}$ & $\begin{array}{c}-0.154^{++} \\
(0.030)\end{array}$ & $\begin{array}{c}-0.042^{++} \\
(0.015)\end{array}$ & $\begin{array}{l}-0.010 \\
(0.016)\end{array}$ & $\begin{array}{l}0.024^{+\dagger} \\
(0.011)\end{array}$ & $\begin{array}{l}0.047^{+\dagger} \\
(0.005)\end{array}$ & $\begin{array}{l}0.028^{+t} \\
(0.011)\end{array}$ & $\begin{array}{c}-0.053^{++} \\
(0.022)\end{array}$ & $\begin{array}{c}-0.023^{++} \\
(0.011)\end{array}$ & $\begin{array}{l}-0.017 \\
(0.012)\end{array}$ \\
\hline Underschooling & - & - & - & $\begin{array}{c}-0.107^{++} \\
(0.018)\end{array}$ & $\begin{array}{c}-0.050^{++} \\
(0.013)\end{array}$ & $\begin{array}{c}0.002 \\
(0.014)\end{array}$ & $\begin{array}{c}0.008 \\
(0.023)\end{array}$ & $\begin{array}{c}0.003 \\
(0.012)\end{array}$ & $\begin{array}{c}0.002 \\
(0.012)\end{array}$ & $\begin{array}{c}-0.036^{+\dagger} \\
(0.007)\end{array}$ & $\begin{array}{c}-0.051^{+\dagger} \\
(0.004)\end{array}$ & $\begin{array}{c}-0.031^{++} \\
(0.010)\end{array}$ & $\begin{array}{l}0.060^{++} \\
(0.020)\end{array}$ & $\begin{array}{l}-0.001 \\
(0.010)\end{array}$ & $\begin{array}{l}0.021^{+t} \\
(0.010)\end{array}$ \\
\hline Married & $\begin{array}{l}-0.021 \\
(0.019)\end{array}$ & $\begin{array}{l}-0.004 \\
(0.010)\end{array}$ & $\begin{array}{c}0.006 \\
(0.012)\end{array}$ & $\begin{array}{c}-0.028^{++} \\
(0.017)\end{array}$ & $\begin{array}{l}-0.010 \\
(0.010)\end{array}$ & $\begin{array}{c}0.006 \\
(0.012)\end{array}$ & $\begin{array}{l}-0.028 \\
(0.018)\end{array}$ & $\begin{array}{l}-0.005 \\
(0.010)\end{array}$ & $\begin{array}{c}0.006 \\
(0.012)\end{array}$ & $\begin{array}{c}-0.025 \\
(0.018)\end{array}$ & $\begin{array}{l}-0.004 \\
(0.010)\end{array}$ & $\begin{array}{c}0.006 \\
(0.012)\end{array}$ & $\begin{array}{l}-0.017 \\
(0.018)\end{array}$ & $\begin{array}{l}-0.004 \\
(0.010)\end{array}$ & $\begin{array}{c}0.007 \\
(0.012)\end{array}$ \\
\hline Age & $\begin{array}{l}0.042^{+\dagger} \\
(0.008)\end{array}$ & $\begin{array}{l}0.036^{+\dagger} \\
(0.004)\end{array}$ & $\begin{array}{l}0.097^{+\dagger} \\
(0.004)\end{array}$ & $\begin{array}{l}0.037^{+\dagger} \\
(0.007)\end{array}$ & $\begin{array}{l}0.035^{+t} \\
(0.004)\end{array}$ & $\begin{array}{l}0.098^{+\dagger} \\
(0.004)\end{array}$ & $\begin{array}{l}0.039^{+\dagger} \\
(0.008)\end{array}$ & $\begin{array}{l}0.035^{+\dagger} \\
(0.004)\end{array}$ & $\begin{array}{l}0.097^{+t} \\
(0.004)\end{array}$ & $\begin{array}{l}0.039^{+\dagger} \\
(0.008)\end{array}$ & $\begin{array}{l}0.035^{+\dagger} \\
(0.004)\end{array}$ & $\begin{array}{l}0.097^{+\dagger} \\
(0.004)\end{array}$ & $\begin{array}{l}0.040^{+\dagger} \\
(0.008)\end{array}$ & $\begin{array}{l}0.036^{+\dagger} \\
(0.004)\end{array}$ & $\begin{array}{l}0.097^{+\dagger} \\
(0.004)\end{array}$ \\
\hline $\operatorname{Age}^{2 *} 10^{-2}$ & $\begin{array}{c}-0.049^{++} \\
(0.010)\end{array}$ & $\begin{array}{c}-0.040^{++} \\
(0.005)\end{array}$ & $\begin{array}{c}-0.036^{++} \\
(0.005)\end{array}$ & $\begin{array}{c}-0.043^{++} \\
(0.009)\end{array}$ & $\begin{array}{c}-0.040^{++} \\
(0.005)\end{array}$ & $\begin{array}{c}-0.036^{++} \\
(0.005)\end{array}$ & $\begin{array}{c}-0.046^{++} \\
(0.010)\end{array}$ & $\begin{array}{c}-0.040^{++} \\
(0.005)\end{array}$ & $\begin{array}{c}-0.035^{++} \\
(0.005)\end{array}$ & $\begin{array}{c}-0.046^{++} \\
(0.010)\end{array}$ & $\begin{array}{c}-0.039^{++} \\
(0.005)\end{array}$ & $\begin{array}{c}-0.036^{++} \\
(0.005)\end{array}$ & $\begin{array}{c}-0.047^{++} \\
(0.010)\end{array}$ & $\begin{array}{c}-0.040^{++} \\
(0.005)\end{array}$ & $\begin{array}{c}-0.036^{++} \\
(0.005)\end{array}$ \\
\hline Tenure & $\begin{array}{l}0.012^{+\dagger} \\
(0.003)\end{array}$ & $\begin{array}{l}0.007^{++} \\
(0.002)\end{array}$ & $\begin{array}{c}0.003 \\
(0.002)\end{array}$ & $\begin{array}{l}0.010^{+\dagger} \\
(0.003)\end{array}$ & $\begin{array}{l}0.007^{++} \\
(0.002)\end{array}$ & $\begin{array}{c}0.003 \\
(0.002)\end{array}$ & $\begin{array}{l}0.011^{+\dagger} \\
(0.003)\end{array}$ & $\begin{array}{l}0.007^{+t} \\
(0.002)\end{array}$ & $\begin{array}{c}0.003 \\
(0.002)\end{array}$ & $\begin{array}{l}0.011^{+\dagger} \\
(0.003)\end{array}$ & $\begin{array}{l}0.007^{+\dagger} \\
(0.002)\end{array}$ & $\begin{array}{c}0.003 \\
(0.002)\end{array}$ & $\begin{array}{l}0.012^{++} \\
(0.003)\end{array}$ & $\begin{array}{l}0.007^{+\dagger} \\
(0.002)\end{array}$ & $\begin{array}{c}0.002 \\
(0.002)\end{array}$ \\
\hline Tenure $^{2} * 10^{-2}$ & $\begin{array}{l}-0.015 \\
(0.011)\end{array}$ & $\begin{array}{c}-0.013^{++} \\
(0.005)\end{array}$ & $\begin{array}{c}-0.014^{++} \\
(0.006)\end{array}$ & $\begin{array}{l}-0.016 \\
(0.010)\end{array}$ & $\begin{array}{c}-0.013^{++} \\
(0.050)\end{array}$ & $\begin{array}{c}-0.014^{++} \\
(0.006)\end{array}$ & $\begin{array}{l}-0.015 \\
(0.010)\end{array}$ & $\begin{array}{c}-0.013^{+\dagger} \\
(0.005)\end{array}$ & $\begin{array}{c}-0.014^{++} \\
(0.006)\end{array}$ & $\begin{array}{l}-0.015 \\
(0.010)\end{array}$ & $\begin{array}{c}-0.013^{++} \\
(0.005)\end{array}$ & $\begin{array}{c}-0.013^{++} \\
(0.006)\end{array}$ & $\begin{array}{l}-0.016 \\
(0.011)\end{array}$ & $\begin{array}{c}-0.013^{t+} \\
(0.005)\end{array}$ & $\begin{array}{c}-0.013^{++} \\
(0.006)\end{array}$ \\
\hline Firm $<20$ & $\begin{array}{c}-0.248^{++} \\
(0.030)\end{array}$ & $\begin{array}{c}-0.118^{+\dagger} \\
(0.014)\end{array}$ & $\begin{array}{c}-0.058^{++} \\
(0.016)\end{array}$ & $\begin{array}{c}-0.230^{++} \\
(0.028)\end{array}$ & $\begin{array}{c}-0.121^{++} \\
(0.014)\end{array}$ & $\begin{array}{c}-0.058^{++} \\
(0.016)\end{array}$ & $\begin{array}{c}-0.240^{++} \\
(0.029)\end{array}$ & $\begin{array}{c}-0.117^{+\dagger} \\
(0.014)\end{array}$ & $\begin{array}{c}-0.058^{++} \\
(0.016)\end{array}$ & $\begin{array}{c}-0.249^{+\dagger} \\
(0.029)\end{array}$ & $\begin{array}{c}-0.120^{+\dagger} \\
(0.014)\end{array}$ & $\begin{array}{c}-0.058^{++} \\
(0.016)\end{array}$ & $\begin{array}{c}-0.247^{+\dagger} \\
(0.029)\end{array}$ & $\begin{array}{c}-0.118^{+\dagger} \\
(0.014)\end{array}$ & $\begin{array}{c}-0.057^{+\dagger} \\
(0.016)\end{array}$ \\
\hline $19<$ Firm $<200$ & $\begin{array}{c}-0.103^{++} \\
(0.024)\end{array}$ & $\begin{array}{c}-0.069^{++} \\
(0.012)\end{array}$ & $\begin{array}{l}0.051^{++} \\
(0.013)\end{array}$ & $\begin{array}{c}-0.100^{++} \\
(0.022)\end{array}$ & $\begin{array}{c}-0.067^{+\dagger} \\
(0.012)\end{array}$ & $\begin{array}{c}-0.050^{++} \\
(0.013)\end{array}$ & $\begin{array}{c}-0.102^{++} \\
(0.024)\end{array}$ & $\begin{array}{c}-0.069^{+\dagger} \\
(0.012)\end{array}$ & $\begin{array}{c}-0.051^{++} \\
(0.013)\end{array}$ & $\begin{array}{c}-0.109^{++} \\
(0.023)\end{array}$ & $\begin{array}{c}-0.069^{+\dagger} \\
(0.012)\end{array}$ & $\begin{array}{c}-0.050^{++} \\
(0.013)\end{array}$ & $\begin{array}{c}-0.102^{++} \\
(0.024)\end{array}$ & $\begin{array}{c}-0.069^{++} \\
(0.012)\end{array}$ & $\begin{array}{c}-0.050^{++} \\
(0.013)\end{array}$ \\
\hline $199<$ Firm<2000 & $\begin{array}{c}-0.087^{++} \\
(0.019)\end{array}$ & $\begin{array}{l}-0.028^{\dagger} \\
(0.010)\end{array}$ & $\begin{array}{l}-0.013 \\
(0.011)\end{array}$ & $\begin{array}{c}-0.068^{++} \\
(0.018)\end{array}$ & $\begin{array}{c}-0.024^{++} \\
(0.011)\end{array}$ & $\begin{array}{l}-0.012 \\
(0.011)\end{array}$ & $\begin{array}{c}-0.079^{+\dagger} \\
(0.019)\end{array}$ & $\begin{array}{c}-0.027^{+\dagger} \\
(0.010)\end{array}$ & $\begin{array}{l}-0.013 \\
(0.011)\end{array}$ & $\begin{array}{c}-0.076^{+\dagger} \\
(0.019)\end{array}$ & $\begin{array}{c}-0.027^{++} \\
(0.011)\end{array}$ & $\begin{array}{l}-0.013 \\
(0.011)\end{array}$ & $\begin{array}{c}-0.079^{++} \\
(0.019)\end{array}$ & $\begin{array}{c}-0.028^{++} \\
(0.010)\end{array}$ & $\begin{array}{l}-0.013 \\
(0.011)\end{array}$ \\
\hline North & $\begin{array}{l}-0.006 \\
(0.024)\end{array}$ & $\begin{array}{c}0.001 \\
(0.022)\end{array}$ & $\begin{array}{c}0.014 \\
(0.047)\end{array}$ & $\begin{array}{l}-0.003 \\
(0.023)\end{array}$ & $\begin{array}{l}-0.002 \\
(0.021)\end{array}$ & $\begin{array}{c}0.015 \\
(0.047)\end{array}$ & $\begin{array}{l}-0.005 \\
(0.024)\end{array}$ & $\begin{array}{c}0.002 \\
(0.022)\end{array}$ & $\begin{array}{c}0.015 \\
(0.047)\end{array}$ & $\begin{array}{l}-0.005 \\
(0.023)\end{array}$ & $\begin{array}{c}0.001 \\
(0.021)\end{array}$ & $\begin{array}{c}0.015 \\
(0.047)\end{array}$ & $\begin{array}{l}-0.008 \\
(0.024)\end{array}$ & $\begin{array}{c}0.003 \\
(0.022)\end{array}$ & $\begin{array}{c}0.019 \\
(0.047)\end{array}$ \\
\hline South & $\begin{array}{c}0.009 \\
(0.021)\end{array}$ & $\begin{array}{c}0.026 \\
(0.020)\end{array}$ & $\begin{array}{l}0.141^{+\dagger} \\
(0.055)\end{array}$ & $\begin{array}{c}0.006 \\
(0.020)\end{array}$ & $\begin{array}{c}0.015 \\
(0.019)\end{array}$ & $\begin{array}{l}0.139^{+\dagger} \\
(0.055)\end{array}$ & $\begin{array}{c}0.008 \\
(0.021)\end{array}$ & $\begin{array}{c}0.025 \\
(0.020)\end{array}$ & $\begin{array}{l}0.141^{++} \\
(0.055)\end{array}$ & $\begin{array}{c}0.008 \\
(0.021)\end{array}$ & $\begin{array}{c}0.025 \\
(0.020)\end{array}$ & $\begin{array}{l}0.140^{+\dagger} \\
(0.055)\end{array}$ & $\begin{array}{c}0.008 \\
(0.021)\end{array}$ & $\begin{array}{c}0.027 \\
(0.020)\end{array}$ & $\begin{array}{l}0.141^{++} \\
(0.055)\end{array}$ \\
\hline Agriculture/Mining & $\begin{array}{c}0.052 \\
(0.062)\end{array}$ & $\begin{array}{c}0.000 \\
(0.051)\end{array}$ & $\begin{array}{l}-0.005 \\
(0.058)\end{array}$ & $\begin{array}{c}0.021 \\
(0.056)\end{array}$ & $\begin{array}{c}0.005 \\
(0.051)\end{array}$ & $\begin{array}{l}-0.013 \\
(0.058)\end{array}$ & $\begin{array}{c}0.037 \\
(0.063)\end{array}$ & $\begin{array}{c}0.002 \\
(0.051)\end{array}$ & $\begin{array}{l}-0.005 \\
(0.058)\end{array}$ & $\begin{array}{c}0.051 \\
(0.059)\end{array}$ & $\begin{array}{c}0.005 \\
(0.051)\end{array}$ & $\begin{array}{l}-0.007 \\
(0.058)\end{array}$ & $\begin{array}{c}0.044 \\
(0.056)\end{array}$ & $\begin{array}{c}0.003 \\
(0.051)\end{array}$ & $\begin{array}{l}-0.005 \\
(0.058)\end{array}$ \\
\hline Production & $\begin{array}{c}0.025 \\
(0.041)\end{array}$ & $\begin{array}{l}0.038^{+\dagger} \\
(0.016)\end{array}$ & $\begin{array}{l}0.051^{++} \\
(0.017)\end{array}$ & $\begin{array}{c}0.043 \\
(0.039)\end{array}$ & $\begin{array}{c}0.037 \\
(0.016)\end{array}$ & $\begin{array}{l}0.050^{+\dagger} \\
(0.017)\end{array}$ & $\begin{array}{c}0.021 \\
(0.040)\end{array}$ & $\begin{array}{c}0.038^{+t} \\
(0.016)\end{array}$ & $\begin{array}{l}0.051^{++} \\
(0.017)\end{array}$ & $\begin{array}{c}0.031 \\
(0.040)\end{array}$ & $\begin{array}{l}0.039^{+\dagger} \\
(0.016)\end{array}$ & $\begin{array}{l}0.051^{++} \\
(0.017)\end{array}$ & $\begin{array}{c}0.029 \\
(0.040)\end{array}$ & $\begin{array}{l}0.039^{+\dagger} \\
(0.016)\end{array}$ & $\begin{array}{l}0.052^{++} \\
(0.017)\end{array}$ \\
\hline Trade & $\begin{array}{l}-0.059 \\
(0.042)\end{array}$ & $\begin{array}{l}-0.017 \\
(0.018)\end{array}$ & $\begin{array}{c}0.009 \\
(0.021)\end{array}$ & $\begin{array}{l}-0.044 \\
(0.041)\end{array}$ & $\begin{array}{l}-0.027 \\
(0.019)\end{array}$ & $\begin{array}{l}-0.008 \\
(0.021)\end{array}$ & $\begin{array}{l}-0.064 \\
(0.042)\end{array}$ & $\begin{array}{l}-0.017 \\
(0.018)\end{array}$ & $\begin{array}{c}0.009 \\
(0.021)\end{array}$ & $\begin{array}{l}-0.050 \\
(0.041)\end{array}$ & $\begin{array}{l}-0.016 \\
(0.018)\end{array}$ & $\begin{array}{c}0.008 \\
(0.021)\end{array}$ & $\begin{array}{l}-0.051 \\
(0.041)\end{array}$ & $\begin{array}{l}-0.016 \\
(0.018)\end{array}$ & $\begin{array}{c}0.009 \\
(0.021)\end{array}$ \\
\hline Services & $\begin{array}{l}0.082^{++} \\
(0.038)\end{array}$ & $\begin{array}{l}0.031^{++} \\
(0.015)\end{array}$ & $\begin{array}{c}0.000 \\
(0.017)\end{array}$ & $\begin{array}{c}0.058 \\
(0.036)\end{array}$ & $\begin{array}{l}0.031^{++} \\
(0.015)\end{array}$ & $\begin{array}{c}0.000 \\
(0.017)\end{array}$ & $\begin{array}{l}0.068^{+} \\
(0.037)\end{array}$ & $\begin{array}{l}0.030^{+t} \\
(0.015)\end{array}$ & $\begin{array}{l}-0.001 \\
(0.017)\end{array}$ & $\begin{array}{l}0.073^{++} \\
(0.037)\end{array}$ & $\begin{array}{l}0.032^{++} \\
(0.015)\end{array}$ & $\begin{array}{c}0.000 \\
(0.017)\end{array}$ & $\begin{array}{l}0.078^{+t} \\
(0.037)\end{array}$ & $\begin{array}{l}0.031^{++} \\
(0.015)\end{array}$ & $\begin{array}{l}-0.000 \\
(0.017)\end{array}$ \\
\hline $\begin{array}{l}\text { Privat Households / } \\
\text { Government }\end{array}$ & $\begin{array}{c}0.026 \\
(0.039)\end{array}$ & $\begin{array}{c}0.023 \\
(0.018)\end{array}$ & $\begin{array}{l}-0.002 \\
(0.020)\end{array}$ & $\begin{array}{c}0.015 \\
(0.037)\end{array}$ & $\begin{array}{c}0.012 \\
(0.018)\end{array}$ & $\begin{array}{l}-0.003 \\
(0.020)\end{array}$ & $\begin{array}{c}0.024 \\
(0.038)\end{array}$ & $\begin{array}{c}0.022 \\
(0.018)\end{array}$ & $\begin{array}{l}-0.002 \\
(0.020)\end{array}$ & $\begin{array}{c}0.033 \\
(0.038)\end{array}$ & $\begin{array}{c}0.023 \\
(0.018)\end{array}$ & $\begin{array}{l}-0.002 \\
(0.020)\end{array}$ & $\begin{array}{c}0.029 \\
(0.038)\end{array}$ & $\begin{array}{c}0.023 \\
(0.018)\end{array}$ & $\begin{array}{l}-0.002 \\
(0.020)\end{array}$ \\
\hline Constant & $\begin{array}{l}1.141^{+\dagger} \\
(0.148)\end{array}$ & $\begin{array}{l}1.170^{+\dagger} \\
(0.087)\end{array}$ & $\begin{array}{c}-0.689^{++} \\
(0.143)\end{array}$ & $\begin{array}{l}0.870^{+\dagger} \\
(0.147)\end{array}$ & $\begin{array}{l}1.268^{+t} \\
(0.086)\end{array}$ & $\begin{array}{c}-0.356^{++} \\
(0.107)\end{array}$ & $\begin{array}{l}1.118^{+\dagger} \\
(0.149)\end{array}$ & $\begin{array}{l}1.152^{++} \\
(0.087)\end{array}$ & $\begin{array}{c}-0.695^{++} \\
(0.144)\end{array}$ & $\begin{array}{l}1.062^{+\dagger} \\
(0.148)\end{array}$ & $\begin{array}{l}1.157^{+\dagger} \\
(0.087)\end{array}$ & $\begin{array}{c}-0.672^{++} \\
(0.144)\end{array}$ & $\begin{array}{l}1.080^{++} \\
(0.148)\end{array}$ & $\begin{array}{l}1.171^{+\dagger} \\
(0.087)\end{array}$ & $\begin{array}{c}-0.669^{++} \\
(0.144)\end{array}$ \\
\hline $\mathrm{R}^{2}$ & 0.575 & 0.551 & 0.039 & 0.606 & 0.563 & 0.026 & 0.584 & 0.557 & 0.039 & 0.606 & 0.558 & 0.038 & 0.583 & 0.554 & 0.038 \\
\hline
\end{tabular}

